\title{
İNOVASYONUN EKONOMİK BÜYÜMEYİ ETKİLEMESİNE YÖNELİK BİR YAPISAL EŞİTLIKK MODELİ UYGULAMASI: G20 GRUBU ÜLKELERİ ÖRNEĞİ
}

Furkan Fahri ALTINTAŞ ${ }^{1}$

\author{
Received Date (Başvuru Tarihi): 6/08/2020 \\ Accepted Date (Kabul Tarihi): \\ $19 / 11 / 2020$ \\ Published Date (Yayın Tarihi): \\ $10 / 12 / 2020$
}

ÖZ

Anahtar Kelimeler:

İnovasyon,

Küresel İnovasyon Endeksi,

Ekonomik Büyüme,

Etkileme

JEL Kodlart:

O31,

040
Litaratürde ve nicel araştırmalarda belirtildiği gibi inovasyon ekonomik büyümeyi să̆layan en önemli etkenlerdendir. Bu kapsamda çalışmanın amacl, 2008-2019 yıl aralığındaki G20 grubu ülkelerinin küresel inovasyon endeksi ve ekonomik büyüme göstergelerine ait veriler üzerinden inovasyonun ekonomik büyümeye olan etki değerini, söz konusu etkilemede en hassas inovasyon göstergesini ve göstergelerin önemlilik değerlerini yaptsal eşitlik modellemesi ile tespit etmektir. Araştırmada ilk olarak inovasyonun ekonomik büyümeyi etkileme modelinin doğrulayıcı faktör analizi ile yapısal olarak geçerliliği sağlanmıştır. Devamında bulgulara göre, inovasyonun ekonomik büyümeyi anlaml, pozitif yönlü ve yüksek seviyede etkilediği belirlenmiştir. Ayrnca iş gelişmişliği inovasyon göstergesinin ekonomik büyümeyi etkilemedeki en hassas gösterge olduğu saptanmıştır. Bunun yanında kurumlar ile beşeri sermaye ve araştırma inovasyon göstergelerinin inovasyon boyutunun ekonomik büyümeyi etkilemesindeki etkisel yaprya en fazla katkı sağlayan göstergeler olduğu sonucuna ulaşılmıştır.

Keywords: Innovation, Global Innovation Index, Economic Growth, Influence

JEL Codes:

O31

$\mathrm{O} 40$

\footnotetext{
${ }^{1}$ Dr, Jandarma Genel Komutanlığı, furkanfahrialtintas@yahoo.com,
}

https://orcid.org/0000-0002-0161-5862

Business \& Management Studies: An International Journal Vol::8 Issue:4 Year:2020, 723-763

Bu makale, araştırma ve yayın etiğine uygun hazırlanmış ve 


\section{EXTENDED ABSTRACT}

\section{IMPLEMENTATION OF A STRUCTURAL EQUALITY MODEL TOWARDS INNOVATION AFFECT ECONOMIC GROWTH: G20 GROUP COUNTRIES EXAMPLE}

\section{LITERATURE}

\subsection{RESEARCH SUBJECT}

Schumpeter (1943) states that with the theory of "creative destruction", old technologies will be replaced by new technologies and this can provide economic growth. The new Schumpeterist view, which revises Schumpeter's relationship between innovation and economic growth, confirms the positive relationship between innovation and economic growth, and explains that this relationship does not always have a linear structure. In addition, the new Schumpeterist view thinks that the steps of the states in the fields of science, technology and industry will add more quality to the relationship between innovation and economic growth (Verspagen, 2004).

Within the scope of neoclassical or exogenous growth model, it is explained in Solow's (1956) growth theory that innovation affects economic growth. Because in this theory, it is stated that innovation can be taken as an external variable and technical development and economic growth can be achieved in a stable way thanks to innovation. In this context, Solow (1956) considered the technological dimension as an external factor and thought that the part of labor and capital variables that cannot meet or explain economic growth is achieved by technological development.

Romer (1986), which has an important role in the development of endogenous growth models, states that the drivers of economic growth are innovation activities, especially those related to R\&D studies. Romer (1986) emphasized the necessity and importance of technological innovation activities especially for long-term growth.

In addition, Aghion and Howitt (1992) stated that in terms of endogenous growth theories, the $R \& D$ dimension in the relationship between innovation and economic growth is the main function of economic growth within the scope of innovation activities. Especially Aghion and Howitt (1992) states that vertical innovations developed in a competitive environment provide economic growth. Because with the vertical innovations realized, patents and a new product formation emerge in the competitive environment. With the innovations obtained in question, subsequent innovation activities will be encouraged more meaningfully. This will increase the momentum for innovation and consequently the sustainability of economic growth and development will be achieved.

Accordingly, countries should take into account their innovation activities in order to have economically sound structures. Because innovation functions for countries to increase their ability to endure the competitive environment and to gain competitive advantage. In this context, countries will be able to achieve economic growth by achieving competitive advantage, and consequently, countries will be able to increase their employment, society's quality of life, living standards and human development levels. The main reason for this is that innovation has a structure that ensures efficiency. Therefore, innovation provides economic growth and indirectly the formation of other economic structures and social developments.

\subsection{RESEARCH PURPOSE AND IMPORTANCE}

The purpose of the study is to determine the impact value of the innovation dimension on economic growth, the most sensitive indicator (variable) in the impact of the innovation dimension on economic growth, and the significance values of the indicators (contribution values to the effective structure) within the scope of the literature-supported innovation dimension affecting the economic growth model.

When the national and international literature is evaluated, there is no study that explains the relationship between the global innovation index indicators and economic growth indicators within the scope of G20 countries with structural equation modeling in the 2008-2019 time period. Therefore, this research is the first study found in the literature that complies with the specified features. 


\subsection{CONTRIBUTION of the ARTICLE to the LITERATURE}

This study has contributed to the literature within the scope of empirical findings showing that innovation, which has a theoretical background, provides economic growth like other studies identified. In addition, by determining the contribution values of the indicators or variables in the effective structure between the economic growth dimension of the innovation, it will be possible to determine which innovation or economic growth indicators should be given importance or which innovation or economic growth indicators to increase their performance in order to make the impact of innovation on economic growth more meaningful. Apart from these, the findings determined as a result of the research are a data set for researchers.

\section{DESIGN AND METHOD}

\subsection{RESEARCH TYPE}

In this study, the effect of the innovation dimension on economic growth within the scope of the values belonging to the components or variables representing the global innovation index of the G20 countries and economic growth for the year 2020 was examined by structural equation modeling.

\subsection{RESEARCH PROBLEMS}

The problem of the study is the structure of innovation affecting economic growth, the level of contribution to the relationship structure of indicators between innovation and economic growth, and the sensitivity values of indicators in the relationship structure in question.

\subsection{DATA COLLECTION METHOD}

The data set of the research was created from the global innovation indices of the G20 group countries in the relevant reports between the years 2008-2019 and the values of the indicators that determine the economic growth. Country data for the economic growth factor was obtained from the website www.data.imf.org.

\subsection{QUANTITATIVE / QUALITATIVE ANALYSIS}

Findings determined within the scope of the aims of the research were determined by the method of structural equation model.

\subsection{RESEARCH MODEL}

The model of the research was created within the scope of the effect of the innovation dimension on the economic growth dimension, based on the values of the global innovation index and economic growth indicators of the G20 group countries between the years 2008-2019. In this framework, the indicators used in the research are shown in Table 1 and the model of the research is shown in Figure 1.

Table 1. Indicators Used in the Study

\begin{tabular}{|c|c|c|c|}
\hline \multicolumn{2}{|c|}{ Global Innovation Index (GII) } & \multicolumn{2}{c|}{ Economic Growht (EG) } \\
\hline Indicators & Abbreviations & Indicators & Abbreviations \\
\hline Institutions & INS & \multirow{2}{*}{$\begin{array}{c}\text { Nominal Gross } \\
\text { Domestic Product }\end{array}$} & \multirow{2}{*}{ NGDP } \\
\hline Human Capital and Resarch & HCR & Real Gross Domestic \\
Pnfrastructure & INF & \multirow{2}{*}{ RGDP } \\
\hline Market Sophistication & MS & Product & \\
\hline Business Sophistication & BS & KTO & \\
\hline Knowledge and Technology Output & CO & &
\end{tabular}




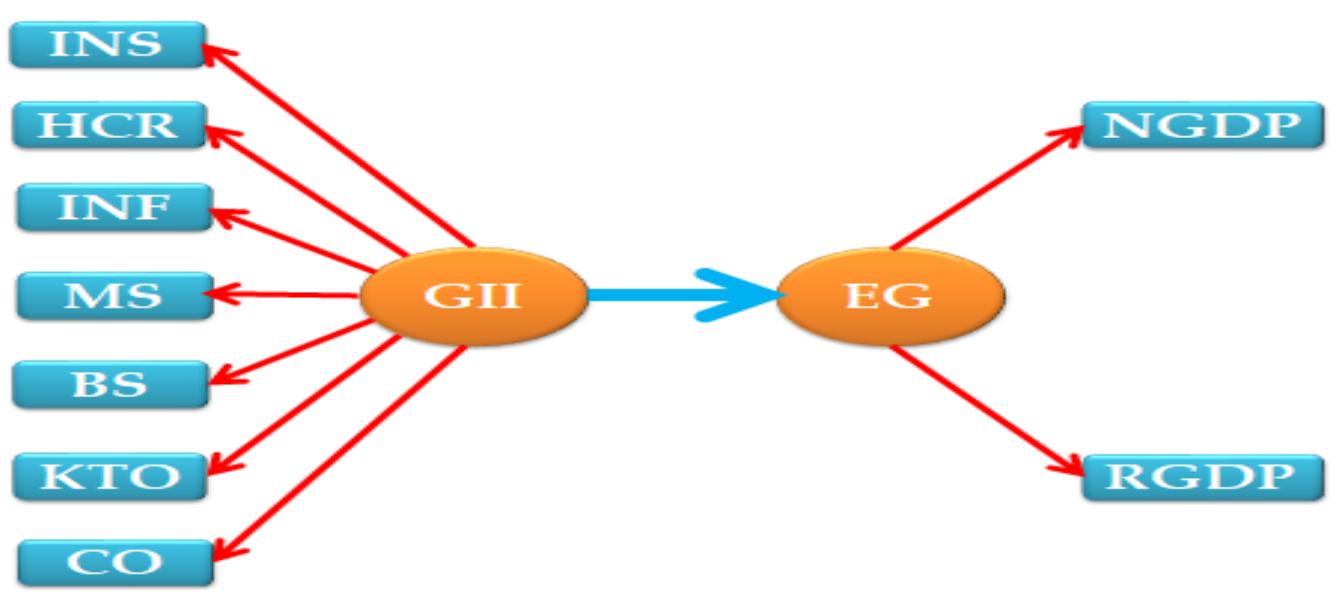

Figure 1. Research Model

\section{FINDINGS AND DISCUSSION}

\subsection{FINDINGS as a RESULT of ANALYSIS}

Firstly, confirmatory factor analysis was applied to test the conformity of the model to the structure. It was evaluated that the confirmatory factor analysis most suitable for the said structure was primary level confirmatory factor analysis. According to the findings, it was observed that the innovation dimension (global innovation index) had a high impact on economic growth and the model created was confirmed. In the study, it was concluded that the most sensitive indicator for the effect of innovation dimension on economic growth for G20 countries is BS (Business Sophistication). Because, as the innovation dimension affects economic growth, it has been determined that the unit change in the innovation dimension changes the innovation indicator BS more than the other innovation indicators. This is due to the fact that qualified employees and knowledge concentration have a structure that will ensure economic growth. Accordingly, G20 countries primarily focused more on business development, which is one of the fundamentals of economic development in achieving economic growth.

According to G20 countries, it has been determined that the most important innovation indicators in the impact of the innovation dimension on economic growth are INS and HCR. Because, compared to the G20 countries, INS and HCR innovation indicators have created more qualified change in economic growth, and they have contributed more than other innovation indicators in affecting and ensuring the economic growth of these indicators. In this sense, the innovation indicators INS (institutions: political environment, regulatory environment and business environment) and HCR (Human Capital and Research: Education, higher education, research and development) in G20 countries to achieve economic growth, by providing more qualified changes in economic growth than other innovation indicators. They have ensured that the current order and stability in economic growth turn into a different order and stability. Therefore, G20 countries have attached more importance to the innovation indicators INS and HCR compared to other innovation indicators in changing the core of economic growth. This may be due to the fact that these indicators have more basic and priority structures compared to other innovation indicators.

\subsection{DISCUSSING the FINDINGS with the LITERATURE}

The research showed consistency with the results of other researchers, except for Shukla (2017), which is mentioned in the literature, within the framework of its significant and positive effects on innovation and economic growth. In this context, this study has contributed to the literature within the scope of empirical findings that innovation provides economic growth, like other studies identified. 


\section{CONCLUSION, RECOMMENDATION AND LIMITATIONS}

\subsection{RESULTS of the ARTICLE}

According to the results of the research, it has been determined that the innovation dimension has a significant, positive and high effect on the economic growth dimension. In the research, it was also found that the most sensitive indicator of the effect of innovation dimension on economic growth dimension is BS (Business Sophistication). It has been determined that the indicators that contribute the most to the relational structure between innovation and economic growth dimensions are INS (Institutions) and HCR (Human Capital and Research).

\subsection{SUGGESTIONS BASED on RESULTS}

G20 countries can further ensure the stability and order of economic growth and economic growth by increasing the relationships and complementarity activities between innovation indicators. Accordingly, G20 countries can raise the high impact of innovation on economic growth to higher levels by primarily increasing the Information and Technology Output (KTO), Creative Output (CO) and Market Sophistication (MS) and other innovation indicators. In this way, G20 countries will be able to work more intensely on innovation, specialize in innovation and ensure that innovation systems, strategies, methods and practices are healthier. In this way, G20 countries will be able to work more intensively on innovation, specialize in innovation and ensure that innovation systems, strategies, methods and practices are healthier. In this sense, the innovation dimension is not only economic growth, but also different (economic development, competitive advantage, economic development) and indirectly affected areas (science, technology, art, sports, medicine, quality of life, welfare level, living standard) will be able to contribute to their development in a healthy way.

Except for the countries in the G20 group, other countries should first take actions to positively increase the relational structure between innovation indicators in order to achieve their overall economic growth. Later, countries, just like the G20 countries, can create activities that will improve the performance of other innovation indicators of INS and HCR innovation dimensions, which have a basic and prioritized structure for the innovation dimension to affect economic growth, and that will concern economic growth.

It may be suggested for researchers to compare the effects of the innovation dimension on the economic dimension by using other indices or metrics that measure the innovation performance of countries. Thus, the nature of innovation indicators for economic growth can be discussed within the framework of causality analysis. In addition, in measuring the innovation performance of countries, the number of indicators can be increased or indicators specific to each country can be created. In this way, more realistic results can be achieved in determining the impact of innovation on economic growth by evaluating the innovation capabilities, capacities and potentials of countries in a multidimensional way.

\subsection{LIMITATIONS of the ARTICLE}

The data set of the research was created from the global innovation indices of the G20 group countries in the relevant reports between the years 2008-2019 and the values of the indicators that determine the economic growth. The first report of the global innovation index was published in 2007. However, the 2007 global innovation index report could not be included in the scope of the study, since only the innovation indicators of certain countries were included in the 2007 report. Currently, there is the latest global innovation index report for 2019. 


\section{GİRIŞ}

İnovasyon, küreselleşme ile birlikte ülkeler için gereksinim halini almıştır. Çünkü inovasyon, organizasyonların ve büyük organizasyonlar olarak nitelendirilen ülkelerin hemen hemen her alanda gelişmesini sağlayan yenilik faaliyetlerini içermektedir. İnovasyonun temel yapısı farklılaşmaya ve çeşitlenmeye dayanmaktadır. Bu kapsamda ülkeler ve organizasyonlar inovasyon faaliyetleri ile ekonomik anlamda ilerleme, gelişme ve kalkınma sağlayabileceklerdir.

İnovasyon, organizasyonların ve ülkelerin koşul bağımlılık kuramı çerçevesinde niceliğinin ve niteliğinin değişme ivmesi fazla olan çevre koşullarına uyum sağlamada önemli bir rol oynamaktadır. Çünkü inovasyon faaliyetleri ile koşulsal durumlara hâkimiyet sağlanıp çevre değişkenleri kontrol altında tutulabilmektedir. Dolayısıyla özellikle inovasyon faaliyetlerine önem veren ülkeler ve organizasyonlar dünya genelindeki değişimleri iyi analiz edebilmekte ve ihtiyaçlara göre oluşabilecek değişimlerin tahmininin doğruya yakın olmasını sağlayabilmektedirler.

İnovasyon faaliyetleri ile ülkeler ve organizasyonlar ekolojik kuram ${ }^{3}$ çerçevesinde ilişkili olduğu çevre içinde tutunma sağlayabileceği için yine çevre içinde (piyasada-pazarda) kendi varlıklarını gösterebilmektedirler. Dolayısıyla bu durum, ülkelerin ve organizasyonların çeşitli faaliyetlerinde kurumsallaşmalarını ve onların meşruiyet yapılarının sağlamlaşmasını sağlayabilmektedir. Böylelikle ülkeler ve organizasyonlar, rekabet ortamında kendi varlıklarını sürdürebilecekler ve rekabet üstünlüklerini elde edebileceklerdir.

Ülkelerin inovasyon faaliyetlerinin sürdürülebilirliğini sağlamaları çok önemlidir. Çünkü küreselleşme ile birlikte ülkeler arasındaki rekabetin varllğ̆1 ve sıklığı kaçınılmazdır. Dolayısıyla ülkeler, inovasyon faaliyetlerinin devamlılığııı sağlayarak sonraki inovasyon faaliyetlerinin oluşmasına ve inovasyon faaliyetlerinin çok yönlü gelişmesine katkı sağlayabilmekte ve çevre içinde farklılaşmayı ve çeşitlenmeyi oluşturabilmektedirler. Böylelikle inovasyon faaliyetlerin devamlılığı,

\footnotetext{
2 Örgüt tasarımlarındaki ya da örgütlenme modellerindeki işleyişleri ve farklılıkları açıklayan kuramdır.
}

${ }^{3}$ Örgüt kurulma ve kapanma oranlarını inceleyen kuramdır. 
inovasyonun sinerjik bir özelliğe kazanmasına neden olabilmektedir. Buna bağl1 olarak ülkeler, ekonomik büyümeyi, gelişmeyi ve kalkınmayı sağlayabileceklerdir. İnovasyon faaliyetleri ile sağlanabilecek olan ekonomik yönden gelişme ile ülkelerin toplumsal gelişimi de gerçekleşebilecektir.

Ülkelerin kendi inovasyon potansiyellerini bilmeleri, yine ülkelerin sonraki inovasyon stratejilerinin, yöntemlerinin, yönetimlerinin ve politikalarının oluşturulmasında büyük önem arz etmektedir. Ayrıca ülkeler, birbirlerinin inovasyon konusundaki üstünlüklerini öğrenerek inovasyon faaliyetleri kapsamında birbirleri ile işbirlikleri oluşturabilmektedirler. Böylelikle ülkeler, küresel anlamda inovasyonun gelişimine ve buna bağlı olarak dünya ekonomisinin gelişimine katkı sağlayabilmektedirler. Dolayısıyla ülkeler, kendilerinin ve birbirlerinin inovasyon potansiyellerini uluslararası alanda ölçen metriklere, ölçütlere veya endekslere gereksinim duyarlar. $\mathrm{Bu}$ kapsamda ülkelerin küresel boyutta inovasyon performanslarını ölçen ölçütlerden biri olan küresel inovasyon endeksi, her yıl ülkelerin inovasyon endeksini oluşturan göstergelere ait değerler ile ölçülmektedir.

İnovasyon ekonomik büyümeyi sağlayan en önemli faktörlerden biridir. Bu durum ilgili literatür kapsamında birçok bilimsel araştırmada belirtilmiştir. $\mathrm{Bu}$ çalışmada da dünya ekonomisinin yarısından fazlasına hâkim olan G20 ülkelerine ait ilgili göstergeler üzerinden inovasyonun ekonomik büyümeye olan etkisi araştırılmıştır.

\section{KAVRAMSAL ÇERÇEVE}

\section{1. İnovasyon ve Küresel İnovasyon Endeksi}

İnovasyon kelimesi etimolojik olarak Latince "innovatus" kelimesinden türetilmiştir. İnnavatus kelimesi ise yenilemek (fare nouva) ve yenilenmek (innovare) ve yeni (neo) kelimelerinin bileşkesinden oluşmaktadır (Giunchiglia, 2003, s. 2). İnovasyon bu anlamda mevcut bilgi birikiminin daha ötesinde mevcut çıktıları, çıktı süreçlerini, organizasyon oluşturma ve yönetim stratejilerini, koşul bağımlılık kuramı çerçevesinde duruma göre toplum için fayda sağlamayı ve daha öncesiyle ilişkili fakat farklı olarak ortaya sunma durumlarını kapsamaktadır (Tunçbilek ve Bayrakçı, 2017, s. 51). 
İnovasyon kavramı ilk olarak Schumpeter tarafından kullanılmış ve inovasyon "kalkınmanın itici gücü" olarak belirtilmiştir. Bu kapsamda Schumpeter (1934), ekonomik gelişimler ve değişimler üzerinde yoğunlaşarak "yaratıı yıkım (creative destruction)" kavramina değinmiştir. Söz konusu "yaratıcı yıkım" kavramı ise değişim ve gelişim sonucunda eski teknolojilerin yerine inovasyon faaliyetleri ile yeni teknolojilerin kullanılması olarak açıklanmıştır.

Schumpeter (1934), değişim ve gelişim sonucunda inovasyonun bütünsel ve kısmi olabileceğini değerlendirmiştir. Bütünsel inovasyon faaliyetleri tamamen bilimselliğe dayanan organizasyonlar için yeniliklerin oluşmasına dayanmaktadır. Bütünsel inovasyon faaliyetlerinde önemli olan sistemin yenilenmesidir. Kısmi yenilenme ise ürünlerin ve hizmetlerin oluşturulması ve ürünlerden ve hizmetlerden faydalanma sürecinde yerine ve zamana göre fayda getirici şekilde oluşan değişimlerin oluşturulmasını kapsamaktadır.

İnovasyon kavramı Oslo klavuzuna göre (OECD ve Eurostat, 2005, s. 50), organizasyonun iç ve diş uygulamalarında daha yeni veya daha gelişmiş sağlamlaştırılan ürünlerin ve hizmetlerin oluşturulması süreci veya sonucu çerçevesinde yeni bir pazarlama metodu veya organizasyonel yönetimin sağlanması olarak açıklanmıştır. Bu kapsamda inovasyonun süreç kısmını yenileme ve yenilenme faaliyetlerini, sonuç kısmın ise yenileme ve yenilenme sonucu oluşan fayda sağlayacak getiri ve katma değer oluşturmaktadır (Mytelka ve Farinelli, 2000).

İnovasyon ve yenilik kavramları birbirleri ile bağlantılı olup, söz konusu kavramların birbirinden farkları bulunmaktadır. Bu anlamda inovasyon kavramı yenilik kavramının öz alt kümesidir. Dolayısıyla her inovasyon kavramı yenilik kavramına dâhil olmaktadır. Buna karşın her yenilik kavramı ise inovasyonu açıklamamaktadır. İnovasyon kavramının yenilik kavramından ayıran asıl nokta, inovasyon ile yapılan faaliyetlerin fayda, katma değer ve olumlu getiri sağlamasıdır (Esmer, Yüksek ve Şaylan, 2019).

İnovasyon çeşitleri temel anlamda dört boyutta kategorize edilmiştir. Söz konusu inovasyon çeşitleri ve onların açıklamaları aşağıda maddeler halinde sunulmuştur (OECD ve Eurostat, 2005, s. 53-55). 
1. Ürün ve Hizmet İnovasyonu: Bir ürünün veya hizmetin var olan halinden daha çok iyileşmiş veya sağlamlaşmış durumunu belirtmektedir. Böylelikle ürünün veya hizmetin teknik özelliklerinde iyileşme durumu sayesinde üründen veya hizmetten faydalananlar kolaylık sağlayacaktır.

2. Süreç İnovasyonu: Mevcut durumuna göre daha çok iyileştirilen ve sağlamlaştırılan çıtıların veya hizmetlerin üretilmesi ve teslimat yöntemlerinin oluşturulmasıdır. Söz konusu bu yenilikler, ürün veya çıktı için sağlanan tekniklerin veya malzemelerin yazılımlarının yenilenmesini içermektedir.

3. Pazarlama İnovasyonu: Ürünün tasarımında, ambalajlanmasında, konumlandırılmasında ve fiyatlandırılmasında geliştirilen yenilik faaliyetlerini kapsamaktadir.

4. Organizasyonel İnovasyon: Organizasyonların ticari ve ekonomik faaliyetlerinde ve organizasyonların çevresindeki ilişkilerde yeni organizasyonel yöntemlerin oluşturulmasıdır.

Bazı literatürde ise inovasyon türleri yönetim, stratejik, açık, iş modeli, alt pazar ve ters inovasyon olarak açıklanmıştır (Soylu, Ceylan ve Özdipçiner, 2019). İnovasyon türleri sayesinde organizasyonlar ve büyük organizasyonlar olarak nitelendirilen ülkeler, ürünlerin ve hizmetlerin sürekli olarak geliştirilmesini sağlayabilmektedirler. Dolayısıyla organizasyonlar ve ülkeler belirtilen inovasyon türlerini ideal yerde ve zamanda uygulayarak ekonomik anlamda uzun vadede olumlu getiri sağlayabileceklerdir (Burmaoğlu, 2012, s. 193).

İnovasyonun temel amacı, bilgiyi üretmek, geliştirmek ve toplum için fayda sağlayabilecek oluşumlar gerçekleştirmekdir. Dolayısıyla inovasyonun özünü oluşturan yeni sistemler ve yapılar sayesinde organizasyonlar ve ülkeler inovasyon faaliyetlerinde gereksinim duyulabilecek seri teknolojik değişimi ve küresel anlamda rekabetin sürdürebilirliğini sağlayabileceklerdir. Bunun yanında kurumların birbirleri ile olan yeniliğe yönelik ilişkileri, inovasyonun gelişmesini sağlayan diğer sebeplerdendir (Işık ve Kılınç, 2012, s. 16).

Marquis (1969), inovasyon ile ilgili olarak yaptığı araştırmalarda kökten değişime dayanan basamaksal ve sistematik inovasyon türünden söz etmiştir. 
Kökten değişmeye dayanan inovasyon, daha önce uygulanmamış inovasyon türünü, basamaksal inovasyon kademeli olarak yapılan iyileştirme türünü, sistematik inovasyon ise daha çok neden-sonuç ilişkisine dayandırılarak inovasyonu sağlayacak sistemi oluşturan öğelerin birbirleri ile olan ilişkisel yapı türünü açıklamaktadır.

İnovasyon faaliyetlerinin ülkelerin ekonomik büyümesinde, gelişim göstermesinde ve kalkınmanın sağlanmasında çok önemli bir rolü bulunmaktadır. Çünkü inovasyon faaliyetleri ile alışılmışların dışında ve alışılmışlardan farklı olarak piyasa veya pazara yeni ürünler, hizmetlerin ve ürünlerin çıktı olarak sağlanmasına yönelik yeni stratejiler, uygulamalar ile yönetimler oluşturulmaktadır. Bunun yanında inovasyon ile lojistik, girişimcilik, bilim ve teknoloji altyapısı, kaynaklar ile sermaye sağlamlaşabilecektir (Porter, 1990; Drucker, 2002).

İnovasyon faaliyetleri ile verimlilik arasında pozitif yönlü sıkı bir ilişki bulunmaktadır. İnovasyon gelişimi ile bağlantılı olarak verimlilik sayesinde bir ülkede sosyal ve insani kalkınma ile çevrenin korunması sağlanabilecek, ekonomik anlamda istihdam niteliği ve niceliği artabilecek, kaynakların kullanımında etkinlik, etkililik ve verimlilik oluşturulabilecektir (Uzgören, 1999, s. 172; Szirmai, Naudé ve Goedhuys, 2011, s. 6). Çünkü inovasyon faaliyetleri ile toplumların amacına yönelik konsantrasyonlarının, belirsizliklerin belirli hale getirilme çabalarının, bilime olan yatkınlıklarının ve katkılarının eğitim-öğretim düzeylerinin artmasına neden olabilecektir (Didero, Gareis, Marques ve Ratzke, 2008).

Teknolojik gelişmeler doğrultusunda herhangi bir ülkede gerçekleştirilen inovasyon faaliyetleri ile beslenmiş ürünler ve hizmetler diğer ülkeler tarafından gözlemlenebilmekte ve analizi yapılabilmektedir. Dolayısıyla ülkeler, birbirinden görerek ve anlayarak yapılan inovasyon faaliyetleri ile inovasyona genel anlamda katkı sağlayabilmektedirler. Bu durum, ülkeler arasında inovasyon faaliyetleri kapsaminda en ideal ürünün ve hizmetin oluşturulması için rekabeti oluşturabilecektir. Böylelikle en çok tutulan inovasyon ile desteklenmiş ürünü ve hizmeti sağlayan ve geliştiren ülkeler, rekabet üstünlüğünü ve buna bağlı olarak sürdürülebilir ekonominin oluşturulmasını gerçekleştirebileceklerdir (Aydoğdu, 2013, s. 40). 
İnovasyon kavramının ülkeler için öneminin çok olması ülkelerin inovasyon performanslarının tespit edilmesi gereksinimini doğurmuştur. Çünkü inovasyon, bir ülkenin gelişimine yönelik olarak hemen hemen tüm disiplinler ile ilişki içinde olup, onlara katkı sağlamaktadır. Bu kapsamda ülkelerin bilim, teknoloji, ekonomi, sağlık, sanat, spor, sosyal vb. alanlardaki gelişimlerin ivme kazanmasında inovasyonun büyük payı bulunmaktadır.

Ülkelerin kendi inovasyon performansların bilmeleri ile ülkeler açısından kendi inovasyon potansiyelleri ve kapasiteleri ile ilgili olarak farkındalık oluşacaktır. Böylelikle ülkeler, inovasyon konusundaki eksikliklerinin veya inovasyon konusundaki geliştirilmesi gereken konuların tespitini daha verimli olarak yapabileceklerdir. $\mathrm{Bu}$ durum; ülkelerin inovasyon faaliyetlerin planlanmasinın, stratejilerinin oluşturulmasının, yönetimlerinin, yönelimlerinin ve yatırımların doğru belirlenmesini sağlayarak inovasyon konusunda maliyetleri azaltabilecektir. Devaminda ülkelerin inovasyon konusunda yoğun konsantrasyonu ve etkin faaliyetleri ile sonraki inovasyon faaliyetleri daha sağlıklı ve daha kısa sürede sağlanabilecektir. Dolayısıyla ülkeler, inovasyon oluşturmayı sürekli öğrenme ile pekiştirerek, inovasyonu oluşturulacak yenilik sağlama çabası olarak görmenin yanında, her zaman gerekli ve zorunlu bir oluşum olarak kavrayabileceklerdir. Özet olarak ülkeler, inovasyonun sinerji gücünü anlayarak gelişim için inovasyon faaliyetlerini katmerleştirmek isteyeceklerdir.

Ülkeler ayrıca birbirlerinin inovasyon performanslarını takip edebilmektedirler. Çünkü ülkeler, inovasyon konusundaki eksiklikleri ve geliştirilmesi gereken hususlar hakkında inovasyon performansı, potansiyeli ve yeteneği yüksek olan ülkeler ile işbirlikleri ve ortaklıklar sağlayabilmektedirler. Böylelikle ülkeler, inovasyon konularında birbirlerini tamamlayarak inovasyonun küresel anlamda gelişimine ivme kazandırabilmektedirler. Sonuç olarak ülkeler, kendilerinin ve diğer ülkelerin inovasyon konusundaki potansiyellerini bilme ihtiyaçları oluştuğu için inovasyon performanslarını ölçen ölçütlere, endekslere veya metriklere gereksinim duymaktadırlar. 
Ülkelerin inovasyon performanslarını ölçen uluslararası nitelikte çeşitli endeksler ve ölçütler bulunmaktadır. Söz konusu bu ölçütler ve endeksler; "Küresel İnovasyon Endeksi" (Global Inovation Index), "Avrupa Birliği İnovasyon Birliği Çalışması" (Europan Union Scoreboard Index), İnovasyon Kapasitesi Endeksi (Inovation Capacity Index), Küresel Rekabetçilik Raporu (The Global Competitiveness Report) olarak belirtilmiştir (Aras, Tezcan, Kutlu Furtuna ve Aybars, 2014, s. 89).

Ülkelerin küresel anlamda inovasyon performansları ilk defa 2007 yılında INSEAD isimli işletme eğitimi veren bir kurum tarafından ölçülmüştür (INSEAD, 2007). Devaminda ise küresel inovasyon endeksi ile ülkelerin küresel inovasyon performanslarının ölçüm çalışmasına 2011 yılında Dünya Fikri Mülkiyetler Örgütü (WIPO) (INSEAD ve WIPO, 2011), 2013 yılında ise Cornell Üniversitesi katılmıştır (Cornell University, INSEAD ve WIPO, 2019).

Küresel inovasyon endeksinin oluşturulmasındaki temel hedef, ülkelerin inovasyon konusundaki zenginliklerinin, yeterliliklerinin, potansiyelinin, yeteneklerinin ve eksikliklerinin farkına varılmasını sağlamaktır (Karaata, 2012; Şimşit, Arığlu Akan, Saniye ve Fırat, 2014). Ayrıca bu endeks, her yıl birçok ekonomiyi içeren metrik bir performans ölçümünü açıklamaktadır (Banavente, Dutta ve Wunsch Vincent, 2012).

Küresel inovasyon endeksi girdi ve çıktı alt dizinlerinden oluşmuştur. İnovasyon girdi alt dizinini kurumlar, beşeri sermaye ve araştırma, altyapı, piyasaların gelişmişliği, iş gelişmişliği bileşenlerinden, inovasyon çıktı alt dizini ise bilgi ve teknoloji ile yaratıcı çıtıları bileşenlerinden oluşmaktadır (Jankowska, Matysek, Jedrych ve Mroczek, 2017; Cornell University, INSEAD ve WIPO, 2019). Bu kapsamda küresel inovasyon endeksi alt dizinleri ve alt dizilere bağlı bileşenler Şekil 1 'de gösterilmiştir. 


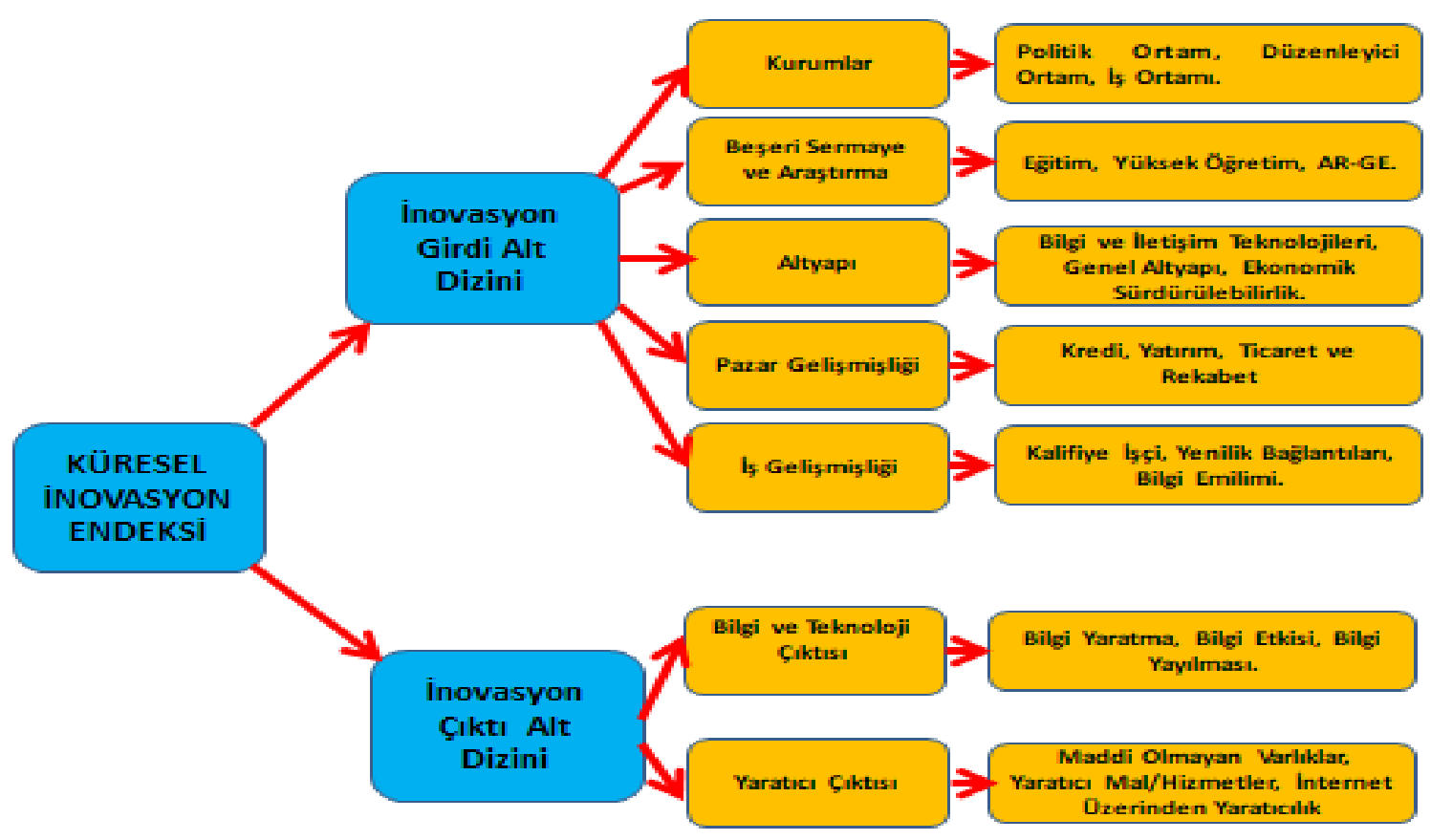

Şekil 1. Küresel İnovasyon Alt Dizinleri ve Alt Dizinlere Bağlı Bileşenler Kaynak: Ay Türkmen ve Aynaoğlu, 2017, s. 262

Şekil 1'de belirtilen küresel inovasyon girdi ve çıktı alt dizinleri sayesinde bir ülkenin küresel inovasyon etkililik, etkinlik ve verimlilik performanslarının hesapları yapılabilmektedir. Bu kapsamda, ülkelerin küresel inovasyon etkililik performansları inovasyon çıktı alt dizininin, inovasyon girdi alt dizinine oranlanması ile tespit edilmektedir (Taş, 2017, s. 112; Hancıoğlu, 2016, s. 130; Kılıç, 2018, s. 3). Bunun yanında inovasyon etkinlik ve verimlilik performansları çeşitli sayısal yöntemler ve çok kriterli karar verme teknikleri ile ölçülebilmektedir.

\subsection{Ekonomik Büyüme}

Ekonomik büyüme, mikro ve makro ölçekler bakımından iki ayrı kategoride açıklanmaktadır. Mikro ekonomik büyüme, bir organizasyon için üretim potansiyelini ve kendi piyasa veya pazar değerinin artması olarak belirtilmektedir. Makro ekonomik büyüme ise genel olarak bir ülkede kişi başına düşen veya toplamdaki üretim artışını açıklamaktadır. Bunun yanında istahdam artışı ve bir üretim faktörüne düşen çıktı miktarı (verimlilik) ekonomik büyümeyi etkileyen değişkenlerdir (Akça, 2018: 31). Kısaca ekonomik büyüme, genel anlamda milli gelirin zaman içindeki artışını ifade etmektedir. Bu açıdan ekonomik büyüme, bir ülkedeki ekonomik yapının hem nitelik hem de nicelik açısından değişimini 
göstermektedir (Demircan, 2003, s. 98-99).

Ekonomik büyüme kavramı ekonomik kalkınma kavramı ile ilişkili olup, birbirinden farklı niteliklere sahiptir. Ekonomik kalkınma, ekonomik büyüme çerçevesinde çıktı dağılımı ile bir ülkenin iktisadi ve üretim yapılarındaki değişimlerdir. Dolayısıyla ekonomik kalkınma; sürdürülebilir ekonomiyi, teknolojik, sosyal, kurumsal ve siyasal anlamda değişim ile toplumların yaşam kalitelerinin, yaşam standartlarının ve insani gelişmişlik seviyelerindeki değişimleri ile yenileşmeyi belirtmektedir. Ayrıca ekonomik kalkınma, ekonomik büyümeye göre daha uzun vadeli bir değişimi ve gelişimi açılamaktadır (Özyakışır, 2011).

Gayri safi yurtiçi hasıla (GSYH) ekonomik büyümenin standart değişkenlerindendir. Çünkü üretilen mal ve hizmet potansiyelinde oluşan artış olarak nitelendirilen ekonomik büyüme, GSYH'nın sürekli olarak artışına neden olmaktadır (Gerguri ve Ramodani, 2010; Çimen ve Sağlam, 2019, s. 158; Evcim, 2019, s. 19).

Ekonomik büyüme, nominal ve reel gayri safi yurt içi hasıla (GSYH) olarak iki biçimde ölçülmektedir. Nominal GSYH, cari fiyatlar dikkate alınarak hesaplanmaktadır. Reel GSYH ise nominal GSYH'nın belirli bir yıla göre değerlendirilmesi ile ölçülmektedir. Reel GSYH, nominal GSYH'nın belirli bir yıldaki nominal GSYH değerinden farkının, yine belirli bir yıldaki nominal GSYH değerine oranının 100 değeri ile çarpılması ile hesaplanmaktadır (Alataş, 2014, s. 4, Evcim, 2017, s. 22).

Bütün ülkelerdeki ekonomik büyüme sürecini işgücünün niteliği ve sayısı, doğal kaynakların niteliği ve sayısı, sermayenin niteliği ve değeri ile ülkeleri oluşturan toplumların ulaştığ1 teknolojik seviye olmak üzere dört ana faktör etkilemektedir. Bu faktörler, her ülkenin iktisadi yapısının üretim kapasitelerini açıklamaktadır. Ayrıca söz konusu bu faktörler, teknoloji oluşturma sürecindeki emeği, doğal kaynakları ve sermaye birleşmelerindeki etkileşimleri açıklamaktadır (Aktuğ, 2003, s. 5).

Ekonomik büyüme teorileri dışsal ve içsel ekonomik büyüme teorileri olarak ikiye ayrılmaktadır. Neoklasik modelde teknolojik gelişmeler, üretim artışının üretim 
faktörleri ile açıklanmayan kısmını oluşturmaktadır. Dolayısıyla teknolojik gelişmeler, neoklasik modelde dışsal bir nitelik kazanmıştır. Çünkü modelde teknolojik gelişmelerin ülkelerin GSYH'sını etkilemesine rağmen, teknolojik gelişmelerin üretim faktörlerinden etkilenmediği varsayılmaktadır (Özel, 2012, s. 64).

1929 ekonomik buhranından sonra para ve maliye politikaların önemi daha da çok artmıştır. Bu kapsamda Keynes ile başlayan ekonomik teoriler, Harrod-Domar'ın farklı çalışmaları ile daha da nitelikli hale gelmiştir (Cesaratto, 1999). Harrod-Domar modelinde devlet ekonomik kararlarda söz sahibi değildir. Ekonomik kararların tümü özel birimler tarafından alınmaktadır. Modelde tüketim ve yatırım için kullanılabilecek sadece bir mal üretilmektedir. Bunun yanında tasarruflar ve verimlilik artışı ekonomik büyümeyi sağlamaktadır (Özel, 2012).

1950 yılında ise Harrod-Domar modelinin eksikliklerini kapatmayı sağlayan çalışmalar yapılmıştır. Bu çalışmalar klasik iktisat temelinde şekillenmiştir. Söz konusu bu çalışmalarda ekonomide tam rekabet koşullarının, emek ve sermaye arasında ikamenin varlığg varsayılarak teknolojinin dışşal bir özelliği bulunduğunu vurgulamaktadır. (Özel, 2012, s. 66). Bu çerçevede Harrod-Domar modelinin temel hipotezi, sermayenin hasılaya olan oranının sabit olmasına dayanmaktadır. Modelin temel yapısal varsayımı iki türlü olarak açıklanabilir. Bunlardan birincisi, hızlandıran bir yatırım işlevi, diğeri ise sabit oranlı üretim fonksiyonu olarak belirtilir. Ayrıca Solow ve Swan gibi iktisatçılar bu çalışmalarda model oluşturulması anlamında öncü olmuş olup, literatürde bu model Neoklasik veya Solow büyüme teorisi olarak bilinmektedir (Ünsal, 2016, s. 84).

Solow (1956), bu modelde nüfus artış hızının, tasarrufun, beşeri sermayedeki üretkenliğin ve teknolojik gelişimin ekonomik büyümede dişşal bir özelliği olduğunu belirtmektedir. Neoklasik büyüme teorisinde iktisadi yapı kapalı olup, piyasalar veya pazarlar rekabet ortamı içindedir. Ayrıca bu teoride veya modelde bireyler rasyonel davranmakta, üretim faktörlerinin, işgücünün ve sermayenin ölçeğe göre azalan getiri kapsamında değerlendirildiği varsayılmaktadır. Bu kapsamda Solow modeli üç temel varsayım üzerine inşa edilmiştir. Bunlardan birincisi, bütün girdiler belirli bir seviyede arttığında, çıktılarında aynı seviyede 
artmasıdır. İkincisi ise üreticilerin ve tüketicilerin fiyat kabul edici pozisyonda olmaları ve piyasalarda veya pazarlarda fiyat arzının ve talebinin eşit kılınmasıdır. Son olarak üçüncü varsayım ise dışsallığın olmadığı durumlarda bir üreticinin diğer üretici için oluşturduğu fiyat ile karşılı̆̆ı olmayan fayda veya yine fiyat ile karşılı̆̆ olmayan maliyetin olmamasıdır (Ünsal, 2016, s. 112).

İçsel büyüme teorileri, genel anlamda neoklasik modelde belirtilen üretim fonksiyonu yerine artan verimlilik yapısı ile açıklanmaktadır. Bu çerçevede teori, teknolojik gelişmenin dışsal bir özelliğinin olmadığını, ekonomik sistemin içinde olduğunu ve ekonomik kararlardan etkilendiğini belirtmektedir. Ayrıca teoride, devlet müdahalelerin optimal büyüme için gerekli olduğunu ve yakınsama teorisinin aksine gelişmekte olan ülkeler ile gelişmiş ülkeler arasında fazla gelir farklarının olmaması için gerekli önlemlerin alınması gerektiği açılanmaktadır (Yülek, 1997, s. 2).

İçsel büyüme teorileri kapsaminda Romer (1986), toplumsal katma değerinin fazla olunduğu konularda devlet müdahalesinin olması gerektiğini belirtmektedir. Ayrıca Romer (1986), Ar-Ge ve teknolojik gelişme değişkenlerinin ekonomik yapı içerisinde içsel bir özelliği olduğunu ve söz konusu değişkenlerin ekonomik büyümeyi doğrudan etkilediğini açıklamaktadır.

Lucas (1988), beşeri sermayenin üretim faktörlerinden biri olduğunu belirtmektedir. Dolayısıyla Lucas (1988), ekonomik büyümenin sağlanması için fiziksel sermayeye ihtiyaç duyulduğu gibi beşeri sermayeye de gereksinim duyulduğunu açıklamıştır. Çünkü Lucas (1988), beşeri sermayenin diğer üretim faktörlerinin verimliliğini artıran bir itici güç olduğunu düşünmüştür. Ayrıca Lucas (1988), fiziksel sermayenin beşeri sermaye ile dengede olması gerektiğini, fiziksel sermayenin beşeri sermayeye göre nispeten oransal anlamda fazla olsa bile ekonomik büyümenin sağlanabileceğini ifade etmiştir.

Barro (1990), kamu politikalarının üretim fonksiyonunda bir değişken olduğunu belirtmiştir. Barro (1990), kamu harcamaları kapsamında vergi politikalarında meydana gelebilecek aksaklıklar ekonomik büyümeyi olumsuz etkileyebileceğini ifade etmiştir. Barro (1990), özellikle özel yatırımların sermayeyi 
artırdığını ve buna bağlı olarak oluşan vergi gelirlerinin denk bütçe aracılığı ile kamu mallarının arzını çoğaltmakta olduğunu açıklamaktadır. Dolayısıyla Barro (1990), özel yatırımların kamu mallarının arzını artırması sebebi ile ekonomik büyümenin içselleşeceğini düşünmüştür.

Grossman ve Helpman (1991), ülkelerdeki teknolojik değişimlerin ülkelerin ticaret yapılarının değişimlerini oluşturacağını ve buna bağlı olarak bu durumun ülkelerin ekonomik büyümelerini pozitif yönde katkı sağlayacağını belirtmişlerdir. Böylelikle araştırmacılar, değişimin teknolojik orjinli olması sebebiyle ülkelerin ticaret faaliyetlerinde mukayeseli veya rekabet üstünlüğünü sağlayabileceğini belirtmektedirler.

\section{3. İnovasyon ve Ekonomik Büyüme İlişkisi}

Ekonomik büyüme teorilerin temeli, Schumpeter'in 1911 yılında öne sürdüğü ekonomik gelişme için inovasyon ve girişimcilik boyutlarının arasındaki ilişkilerin ve tamamlayıcılıkların sağlanması gerektiği görüşüne dayanmaktadır (Brauwer, 2000; Wong, Ho ve Autio, 2005, s. 336). Bunun yanında Schumpeter (1943), "yaratıc1 yıkım" teorisi ile eski teknolojilerin yerini yeni teknolojilerin alacağını ve bunun ekonomik büyümeyi sağlayabileceğini belirtmektedir. Schumpeter'in inovasyon ve ekonomik büyüme ilişkisini revize eden yeni Schumpeterci görüş ise inovasyon ile ekonomik büyüme arasındaki pozitif yönlü ilişkiyi doğrulamakta olup, söz konusu ilişkinin her zaman doğrusal bir yapıya sahip olmadığını açıklamaktadır. Yeni Schumpeterci görüş bu durumun sebebini teknolojinin değişimini, gelişimini ve ilerlemesini sağlayan değişkenlerin niceliğindeki artışa ve niteliğindeki karmaşıklaşmaya bağlamaktadır (Cameron, 1996). Ayrıca yeni Schumpeterci görüş devletin bilim, teknoloji ve sanayi alanlarındaki adımları inovasyon ile ekonomik büyüme arasındaki ilişkiye daha çok nitelik kazandıracağı düşüncesindedir (Verspagen, 2004).

İnovasyonun özellikle teknoloji ile beslenmiş durumunun ekonomik büyümeye olan etkisi nicel ve nitel yöntemler ile sağlam bir şekilde kurgulanmıştır. Bunun temel nedeni, inovasyon boyutunun sürdürülebilir ekonominin sağlanmasında çok büyük öneminin olmasından kaynaklanmaktadır (Wong, Ho ve 
Autio, 2005, s. 336).

Neoklasik veya dişsal büyüme model kapsamında Solow'un (1956) büyüme teorisinde inovasyonun ekonomik büyümeyi etkilediği açıklanmaktadır. Çünkü bu teoride, inovasyon dışsal bir değişken olarak ele alınarak inovasyon sayesinde teknik gelişmenin ve ekonomik büyümenin istikrarlı bir şekilde sağlanabileceği belirtilmiştir. Bu kapsamda Solow (1956), teknolojik boyutu dişsal bir etken şeklinde düşünerek emek ve sermaye değişkenlerinin ekonomik büyümeyi karşılamadığı veya açıklayamadığı kısmının teknolojik gelişme ile sağlandığını düşünmüştür. Böylelikle Solow'un (1956) belirttiği modelde teknoloji ve inovasyon ekonomik büyümede en büyük faktörlerden biri olmuş, fakat inovasyonun ve teknolojinin ekonomik büyümede bu etkenliği artık bakiye olarak dikkate alınmıştır (Gülmez ve Yardımcıŏglu, 2012 akt. Özkul ve Örün, 2016, s. 27).

İçsel büyüme modellerinin ortaya atılmasında önemli bir rolü olan Romer (1986), ekonomik büyümeyi sağlayan lokomotiflerin özellikle Ar-Ge çalışmaları ile ilişkili olan inovasyon faaliyetlerin oluşturduğunu belirtmektedir. Romer (1986), özellikle uzun vadede büyüme için teknolojik anlamda inovasyon faaliyetlerinin gerekliliğini ve önemini vurgulamıştır. Kısacası Romer'a (1986) göre inovasyon, ekonomik büyümeyi pozitif yönlü ve yüksek seviyede etkilemektedir (Gülmez ve Akpolat, 2014, s. 4). Yine Aghion ve Howitt (1992), içsel büyüme teorileri açısından inovasyon ve ekonomik büyüme arasındaki ilişkilerde Ar-Ge boyutunun inovasyon faaliyetleri kapsamında ekonomik büyümeyi sağlamasında temel işlev olduğunu belirtmişlerdir.

Rekabet ortamı içinde geliştirilen dikey yenilikler ekonomik büyümeyi sağlamaktadır. Çünkü gerçekleştirilen dikey yenilikler ile rekabet ortamında patent ve yeni bir mal oluşumu ortaya çıkmaktadır. Söz konusu elde edilen yenilikler ile sonraki inovasyon faaliyetleri daha anlamlı olarak teşvik edilebilecektir. Bu durum, inovasyon oluşma ivmesini artıracak ve buna bağlı olarak ekonomik büyümenin ve gelişmenin sürdürülebilirliği sağlanabilecektir (Aghion ve Howitt, 1992).

İnovasyon boyutu ülkelerin gelişmesinde ve zenginleşmesinde doğrudan bir etkisi bulunmaktadır. İnovasyon ile beslenen yaklaşımlar, toplumların refah 
seviyesine ve ülkelerin ekonomilerine olumlu yönde getiri ve fayda sağlayabilecektir. İnovasyon faaliyetleri kapsamında Ar-Ge çalışmaları yeni teknolojik ürünleri, üretim yöntemlerini, üretim tekniklerini ve stratejilerini geliştirecek olmasından dolayı inovasyondan faydalanan ülkeler diş ticarette rekabet gücü sağlayabileceklerdir. Ülkeler, ekonomik olarak sağlam yapılara sahip olabilmesi için inovasyon faaliyetlerini dikkate almalıdırlar. Çünkü inovasyon, ülkelerin rekabet ortamına katlanabilme seviyelerini yükseltmesinde ve rekabet üstünlüklerini sağlamalarında önemli bir dinamo işlevi görmektedir. Ülkeler bu kapsamda rekabet üstünlüğünü sağlayarak ekonomik büyümeyi elde edebilecekler ve buna bağlı olarak ülkeler istihdamlarını, toplumların yaşam kalitelerini, yaşam standartlarını ve insani gelişmişlik düzeylerini artırabileceklerdir. Bunun temel nedeni ise inovasyonun verimliliği sağlayan bir yapısının bulunmasından kaynaklanmaktadır. Dolayısıyla inovasyon, ekonomik büyümeyi ve dolaylı olarak diğer ekonomik yapıların ve sosyal gelişimlerin oluşumunu sağlamaktadır (Cainelli, Evangelista ve Savona, 2004, s. 116117, Rosenberg, 2004; Pece, 2005; Pessoa, 2007; Tebaldi ve Emlmslie, 2008; Fagerberg, Srholec ve Verspagen, 2009; Elçi, 2007 akt. Özkul ve Örün, 2016, s. 26; Ballı, 2017; Bozan, 2019). Ayrıca amprik araştırmalara göre, ekonomik büyümeye inovasyon ve özellikle inovasyon kapsamında yapılan Ar-Ge faaliyetlerinin somut sermayeden daha fazla katkı sağladığı tespit edilmiştir (Uppenberg, 2009, s. 19).

\section{LITERATÜR}

Literatürde inovasyon ve ekonomik büyüme arasındaki ilişki durumu yöntem bakımından değerlendirildiğinde, inovasyon ve ekonomik büyüme arasındaki ilişkiyi çoğu araştırmacı panel veri analizi ve nedensellik testleri uygulayarak tespit etmişlerdir. Buna karşın yine literatür kapsamında bazı araştırmalarda ekonomik göstergelerin birbirleriyle ve diğer boyutlarla olan ilişkilerin tespitinde farklı istatistik teknikleri de kullanılmıştır. Söz konusu bu araştırmalar ve araştırmalarda kullanılan teknikler Tablo 1'de açıklanmıştır. 
Tablo 1. Ekonomik Göstergelerin Birbirleriyle ve Diğer Boyutlar ile Olan İlişkilerinde Kullanılan Yöntemler

\begin{tabular}{|c|c|c|}
\hline Araştırma/Araştırmacılar & Araştırma Konusu & İstatistik Yöntemi \\
\hline Wong, Ho ve Aito (2005) & İnovasyon ile Ekonomik Büyüme Arasındaki İlişki & Doğrusal Regresyon \\
\hline Uca (2016) & Dış Ticaret Hacminin Küresel Rekabet Endeksine Olan Etkisi & $\begin{array}{l}\text { Yapisal Eşitlik } \\
\text { Modellemesi }\end{array}$ \\
\hline Yorulmaz (2017) & $\begin{array}{l}\text { GSYH'nın ve Sağlık Harcamalarının Sağlık Göstergesine Olan } \\
\text { Etkileri }\end{array}$ & $\begin{array}{l}\text { Yapısal Eşitlik } \\
\text { Modellemesi }\end{array}$ \\
\hline Bilir ve Gökdemir (2018) & $\begin{array}{l}\text { Kişi Başı GSYH'nın ve Ekonomik Büyümenin Yaşam Beklentisine } \\
\text { Olan Etkileri }\end{array}$ & $\begin{array}{l}\text { Yapısal Eşitlik } \\
\text { Modellemesi }\end{array}$ \\
\hline Ural ve Karaömer (2018) & $\begin{array}{l}\text { Borç Oranının Hisse Senedi ile Olan Karşılıklı İlişkisi } \\
\text { (özyinelemesiz-nonrecursive) }\end{array}$ & $\begin{array}{l}\text { Yapısal Eşitlik } \\
\text { Modellemesi }\end{array}$ \\
\hline Başer ve Gökten (2019) & $\begin{array}{l}\text { Kurumsal Kalitenin Ekonomik Gelişmeye (GSYH, kişi başı } \\
\text { GSYH, Ar-Ge harcamaları, teknoloji ihracatı) Olan Etkileri }\end{array}$ & $\begin{array}{l}\text { Yapısal Eşitlik } \\
\text { Modellemesi }\end{array}$ \\
\hline Prasetyo (2019) & $\begin{array}{l}\text { Girişimcilik Kültürünün, Ağ yapıların ve Rekabetin Ekonomik } \\
\text { Büyümeye Olan Etkileri }\end{array}$ & $\begin{array}{l}\text { Yapısal Eşitlik } \\
\text { Modellemesi }\end{array}$ \\
\hline Şahinoğlu ve Yakut (2019) & $\begin{array}{l}\text { Ekonomik Özgürlük Endeksinin Ekonomik Performans Boyutuna } \\
\text { (GSYH, doğrudan yabancı sermaye yatırımları, enflasyon, cari } \\
\text { işlemler açı̆ı̆ı, isssizlik oranları, hükümet borçları ve dışa açıklık } \\
\text { oranı) Olan Etkileri }\end{array}$ & $\begin{array}{l}\text { Yapısal Eşitlik } \\
\text { Modellemesi }\end{array}$ \\
\hline Elverdi ve Atik (2020 & $\begin{array}{l}\text { Girişimciliğin (küresel girişimcilik monitörü) Ekonomik } \\
\text { Büyümeye (kişi başı GSYH) Olan Etkisi }\end{array}$ & $\begin{array}{l}\text { Yapısal Eşitlik } \\
\text { Modellemesi }\end{array}$ \\
\hline
\end{tabular}

Literatür değerlendirildiğinde, inovasyon boyutunun ekonomik büyümeyi etkilemesi konusu ile ilgili olarak birçok araştırma mevcuttur. Literatür incelendiğinde, inovasyon boyutunun ekonomik büyümeyi etkileme durumu çoğu araştırma için anlamlı ve pozitif yönde olduğu sonucuna ulaşılmıştır.

Cainelli, Evangalista ve Savona (2004), 1993-1998 yıl aralığında aralığındaki İtalya'da bulunan hizmet sektöründe faaliyet gösteren 735 firmaya ait veriler üzerinden inovasyon ve ekonomik büyüme arasındaki ilişkiyi doğrusal regresyon yöntemi ile tespit etmişlerdir. Bulgulara göre, inovasyon faaliyetinde bulunan firmaların diğer firmalara göre verimliliklerinin ve ekonomik büyümelerinin daha fazla olduğu ve inovasyonla desteklenen verimlilik faaliyetlerin ekonomik büyümeyi desteklediği sonucuna varılmıştır.

Capello ve Lenzi (2012), 2010 yılı için Avrupa Birliği'ne üye 27 ülke üzerinden bölgesel kalkınmanın inovasyona, inovasyonun ise ekonomik büyümeye olan etkilerini araştırmışlardır. Araştırmada, Ar-Ge destekli bölgesel kalkınmanın inovasyonu, inovasyonun ise ekonomik büyümeyi panel veri analizine göre anlamlı ve pozitif yönde etkilediği tespit edilmiştir. 
Hunady ve Orviská (2014), 2008-2012 y1lları arasında Avrupa Birliği'ne üye ülkelere ait veriler üzerinden inovasyon ve ekonomik büyüme arasındaki ilişkiyi doğrusal regresyon yöntemi ile belirlemişlerdir. Sonuçlara göre, 2012 yılı için ekonomik büyüme ile GSYH (Gayrisafi yurt içi hasıla) anlamlı, pozitif yönde orta düzeyde, inovasyon kapsamında Ar-Ge harcamaları, Ar-Ge çalışan oranı ve patent sayısı ile anlamlı pozitif yönde ve yüksek ilişkiler olduğu bulgularına ulaşılmıştır.

Gülmez ve Akbolat (2014), 2000-2010 zaman aralığındaki Türkiye ve 15 Avrupa Birliği'ne üye ülkelerine, Bozan (2019) 1981-2016 zaman aralığındaki G7 ülkelerine ve Börü ve Çelik (2014) 2004-2016 yılları arasındaki Türkiye'ye ait ilgili değerler (Ar-Ge harcamaları ve patent sayısı) üzerinden inovasyonun ekonomik büyümeye olan etkisini panel veri analizi yöntemi ile araştırmışlardır. Her üç araştırma sonucuna göre, inovasyonun ekonomik büyümeyi pozitif yönlü ve anlamlı olarak etkilediği saptanmıştır.

Galindo ve Mendez (2014), 2002-2014 yılları arasındaki 13 gelişmiş ülke verilerine ait değerler üzerinden girişimcilik, inovasyon ve ekonomik büyüme arasındaki ilişkileri panel veri analizi ile tespit etmişlerdir. Araştırmacılar söz konusu ilişkilere Shumpeterci yaklaşım kapsamında üç denklem oluşturmuşlardır. Sonuçlara göre, ekonomik faaliyetlerin girişimciliği ve inovasyon faaliyetlerini artırdığını ve bu durumun ülkelerin ekonomik büyüme performansını pozitif yönde etkilediği ve artırdığı sonucuna ulaşılmıştır.

Pece, Simona ve Salisteanu (2015), 2000-2013 yılları arasındaki zaman aralığındaki Polonya, Çek Cumhuruiyeti ve Macaristan ülkelerine ait inovasyon ve ekonomik büyüme göstergeleri üzerinden inovasyonun ekonomik büyümeye olan etkisini araştırmışlardır. Araştırmacılar inovasyon göstergeleri olarak ülkelere ait patent sayısı, ticari marka sayısı, Ar-Ge harcamaları, sermaye oranı değerlerinin logaritmik değerlerini, ekonomik büyüme göstergeleri için eğitim harcamaları, işsizlik oranları ve ihracat verilerinin logaritmik değerlerini kullanılmışlardır. Araştırma sonucuna göre, inovasyonun ekonomik büyümeyi anlamlı ve pozitif yönde etkilediği bulgusuna ulaşılmıştır. 
Dam ve Yıldız (2016), 2000-2012 yılları arasındaki BRICS-TM (Brezilya, Rusya, Hindistan, Çin, Güney Afrika, Türkiye ve Meksika) ülkeleri üzerinden Ar-Ge harcamalarının ve inovasyonun ekonomik büyümeye olan etkisini panel veri analizi ile araştırmışlardır. Analiz sonucunda, Ar-Ge harcamalarının ve inovasyonun ekonomik büyümeye pozitif yönlü ve anlamlı etkileri olduğu tespit edilmiştir.

Ballı ve Güreşci (2017), 1996-2014 yılları arasındaki üst ve orta gelir dağılımına sahip ülkeler üzerinden teknolojinin ve inovasyonun ekonomik büyümeye olan etkilerini panel veri analizi yöntemini uygulayarak araştırmışlardır. Araştırmada ekonomik büyüme göstergesi olarak GSYH, teknoloji ve inovasyon göstergeleri olarak her bir ülkenin patent sayısının nüfusa olan oranı ve temel eğitimlerini tamamlamış işgücünün nüfusa olan oranı belirlenmiştir. Bulgular, teknoloji ve inovasyon göstergelerin ekonomik büyümeyi sağladığını göstermiştir.

Evcim (2017), 2010-2014 yılları arasında OECD grubu 36 ülkeye ait veriler üzerinden inovasyon ve ekonomik büyüme arasındaki ilişkiyi araştırmıştır. Araştırmada inovasyon göstergeleri olarak Ar-Ge harcamaları, Ar-Ge harcamalarının GSYH'daki payı ve patent sayıları değişkenleri, ekonomik büyüme göstergesi olarak ise GSYH değişkeni kullanılmıştır. Panel veri analizi sonuçlarına göre, inovasyonun ekonomik büyümeyi anlamlı ve pozitif yönlü etkilediği sonucuna ulaşılmıştır.

Işık (2017), 1995-2015 yılları arasındaki G20 ülkelerine ait inovasyon ve ekonomik büyüme arasındaki ilişkiyi panel veri analizi ile test etmiştir. Araştırma sonucuna göre, inovasyon ve ekonomik büyüme arasında pozitif yönlü ve anlamlı ilişkinin olduğu tespit edilmiştir.

Maradana vd., (2017), 1989-2004 yılları arasındaki 19 Avrupa ülkesine ait verilere istinaden inovasyon ve ekonomik büyüme arasındaki ilişkiyi araştırmışlardır. Araştırmada inovasyon boyutuna ait göstergeler yerli patent sayısı, yabancı patent sayısı, Ar-Ge harcamaları, Ar-Ge faaliyetlerindeki araştırmacı sayısı ve yüksek teknoloji ihracatı, ekonomik büyüme göstergesi olarak ise kişi başı GSYH değişkenleri belirlenmiştir. Araştırma sonucuna göre, tüm inovasyon göstergelerin ekonomik büyümeyi anlamlı ve pozitif yönlü olarak etkilediği gözlenmiştir. 
Shukla (2017), 1996 ile 2011 yılları arasında Hindistan ülkesine ait inovasyon ve ekonomik büyüme göstergeleri üzerinden inovasyonun ekonomik büyümeye olan etkisini araştırmıştır. Araştırmada ekonomik büyüme göstergesi olarak GSYH, inovasyon göstergesi olarak Ar-Ge harcamaları, yabancı yatırımlar, eğitim harcamalarının toplam hasıladaki payı, patent sayısı ve işsizlik oranları kullanılmıştır. Araştırmada inovasyonun ekonomik büyümeye anlamlı etkisinin olmadığ

Thompson (2018), sosyal sermaye, inovasyon ve ekonomik büyüme arasındaki ilişkileri bazı mal ve hizmet sektöründe faaliyet gösteren büyük firmalara ait değerler üzerinden çeşitli matematiksel formüllere dayandırarak oluşturulan modele göre açıklamıştır. Buna göre oluşturulan matematiksel modelde, sosyal sermayenin ilk olarak inovasyonu, inovasyonun ise ekonomik büyümeyi etkilediği tespit edilmiştir.

Çimen ve Sağlam (2019), 2000-2017 yılları arasındaki 28 Avrupa ülkesine ait ilgili veriler üzerinden inovasyonun ekonomik büyümeye olan etkisini araştırmışlardır. Araştırmacılar inovasyon değişkeni olarak Ar-Ge harcamalarını, ekonomik büyüme olarak GSYH (nominal) değişkenini kullanmışlardır. Bulgulara göre, inovasyonun ekonomik büyümeyi pozitif yönlü ve anlamlı olarak sağladığı sonucuna ulaşılmıştır.

\section{METODOLOJİ}

\subsection{Araştırmanın Amacı, Veri Seti, Verilerin Analizi ve Modeli}

Araştırmanın amacı, inovasyon boyutunun ekonomik büyümeye etkileme değerini, inovasyon boyutunun ekonomik büyümeye etkilemesindeki en hassas göstergeyi (değişkeni) ve göstergelerin önemlilik değerlerini (etkisel yapıya katkı değerlerini) tespit etmektir.

Araştırmanın veri seti, G20 grubu ülkelerinin 2008-2019 yılları arasındaki ilgili raporlardaki küresel inovasyon endekslerinden ve ekonomik büyümeyi belirleyen göstergelere ait değerlerden oluşturulmuştur. Küresel inovasyon endeksinin ilk raporu 2007 yılında yayınlanmıştır. Fakat 2007 yılı raporda sadece belirli ülkelerin inovasyon göstergeleri yer aldığı için 2007 küresel inovasyon endeksi raporu 
araştırma kapsamına alınamamıştır. Şu an en son 2019 yılının küresel inovasyon endeks raporu bulunmaktadır. Ekonomik büyüme faktörü için ülkelere ilişkin veriler, www.data.imf.org internet adresinden 2019 yılının Aralık ayında temin edilmiştir. Araştırmada kullanılan küresel inovasyon endeksi ve ekonomik büyüme göstergeleri ile araştırmada kolaylık sağlaması için söz konusu göstergelerin kısaltmaları Tablo 2' de gösterilmiştir.

Tablo 2. Araştırmada Kullanılan Veri Seti

\begin{tabular}{|c|c|c|c|}
\hline \multicolumn{2}{|c|}{ Faktör: Küresel İnovasyon Endeksi (KİE) } & \multicolumn{2}{|c|}{ Faktör: Ekonomik Büyüme (EB) } \\
\hline Göstergeler & Kisaltma & Göstergeler & Kisaltma \\
\hline Kurumlar & Kie1 & \multirow{3}{*}{ Nominal Gayri Safi Yurtiçi Hasıla } & \multirow{3}{*}{ Nominal GSYH } \\
\hline Beşeri Sermaye ve Araştırma & Kie2 & & \\
\hline Altyap1 & Kie3 & & \\
\hline Pazar Gelişmişliği & Kie4 & \multirow{4}{*}{ Reel Gayri Safi Yurtiçi Hasıla } & \multirow{4}{*}{ Reel GSYH } \\
\hline İ̧̇ Gelişmişliği & Kie5 & & \\
\hline Bilgi ve Teknoloji Çıktısı & Kie6 & & \\
\hline Yaratıcı Çıktısı & Kie7 & & \\
\hline
\end{tabular}

Araştırmada G20 grubu ülkelerin verilerinin seçilmesinin nedeni, söz konusu ülkelerin dünyanın en büyük ekonomilerine sahip ve dünya ekonomisinin yarısından fazlasına hâkim olmalarından kaynaklanmaktadır. Dolayısıyla G20 grubunda yer alan ülkelerin inovasyon konusundaki faaliyetleri kendi ekonomik büyümelerini, dünya ekonomisini ve diğer ülkelerin ekonomik büyümeleri ile inovasyon faaliyetlerini etkileyebilmektedir. Araştırmada ayrıca literatüre dayanılarak inovasyon boyutunun ekonomik büyümeyi etkilemesine ilişkin olarak model oluşturulmuştur. Araştırmada modele ilişkin olarak oluşturulan amaçların tespitinde yapısal eşitlik modellemesinden yararlanılmıştır. Verilerin tespiti için AMOS programı kullanılmıştır. Söz konusu model Şekil 2’de gösterilmiştir. 


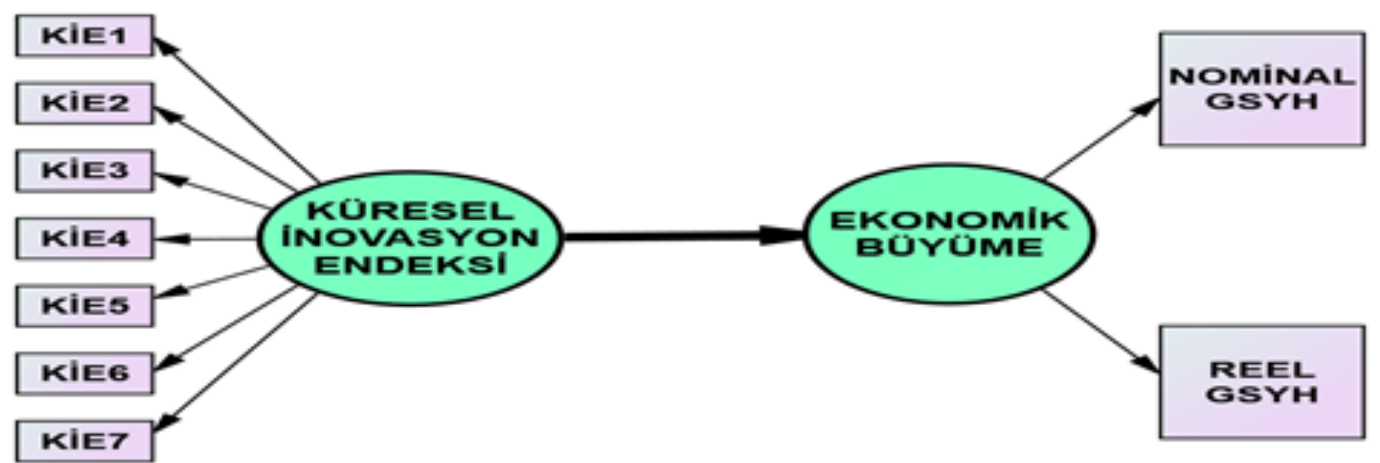

Şekil 2. Araştırmanın Modeli

\subsection{Araştırmanın Önemi ve Katkısı}

Ulusal ve uluslararası literatür değerlendirildiğinde, 2008-2019 zaman aralığında G20 ülkeleri kapsamında küresel inovasyon endeksi göstergeleri ile ekonomik büyüme göstergeleri arasındaki ilişkiyi yapısal eşitlik modellemesi ile açıklayan bir araştırmaya rastlanılmamıştır. Dolayısıyla bu araştırma, belirtilen özelliklere uyan literatürde bulunan ilk araştırmadır. Araştırma sonucunda tespit edilen bulgular araştırmacılar için bir veri seti niteliği taşımaktadır.

\section{BULGULAR}

Araştırmada yol analizinden önce modele göre oluşturulan faktör yüklerinin faktörleri yeterince temsil etme seviyesini ölçmek ve belirtilen modelin yapıya uygunluğunu test etmek için doğrulayıcı faktör analizinin uygulanması gerekmektedir. Doğrulayıcı faktör analizinde verilerin faktör yapısında test edilerek doğrulanması için ilişkisiz seviye, tek faktörlü seviye, birincil seviye ve ikincil seviye modellerin test edilerek oluşturulan modelin söz konusu doğrulayıcı faktör analizi modellerinden hangisinde en iyi uyumun sağladığının test edilmesi gerekmektedir (Meydan ve Şeşen, 2015, s. 25). Bu kapsamda uyum iyiliği değerleri ile araştırma 
modelinin uygulandığı doğrulayıcı faktör analizi modellerinin uyum iyiliği değerleri Tablo 3' de açıklanmıştır.

Tablo 3. Uyum İyiliği Değerleri

\begin{tabular}{|c|c|c|c|c|c|c|}
\hline Ölçüm & İyi Uyum & $\begin{array}{c}\text { Kabul Edilebilir } \\
\text { Uyum }\end{array}$ & İlişkisiz & $\begin{array}{c}\text { İkincil } \\
\text { Seviye }\end{array}$ & $\begin{array}{c}\text { Tek } \\
\text { Faktörlü }\end{array}$ & $\begin{array}{c}\text { Birincil } \\
\text { Seviye Mod. } \\
\text { Sonrası } \\
\text { Değerler }\end{array}$ \\
\hline Ki-kare $\left(X^{2}\right)$ & $0 \leq \mathrm{X}^{2} \leq 2 . \mathrm{sd}$ & $2 . \mathrm{sd} \leq \mathrm{X}^{2} \leq 3 . \mathrm{sd}$ & 89,36 & 114,7 & 96,92 & 77,85 \\
\hline Anlamlılik $(\boldsymbol{p})$ & $0,05<p \leq 1,00$ & $0,01<p \leq 0,05$ & 0,040 & 0,070 & 0,020 & 0,060 \\
\hline Kikare/sd( $\left.\mathrm{X}^{2} / \mathrm{sd}\right)$ & $0 \leq \mathrm{X}^{2} / \mathrm{sd} \leq 2$ & $2 \leq \mathrm{X}^{2} / \mathrm{sd} \leq 3$ & 3,309 & 3,586 & 3,342 & 2,994 \\
\hline SRMR & $0 \leq \mathrm{SRMR} \leq 0,05$ & $0,05 \leq \mathrm{SRMR} \leq 0,10$ & 0,100 & 0,150 & 0,120 & 0,090 \\
\hline GFI & $0,950 \leq \mathrm{GFI} \leq 1$ & $0,90 \leq \mathrm{GFI} \leq 0,95$ & 0,710 & 0,690 & 0,695 & 0,910 \\
\hline AGFI & $0,90 \leq \mathrm{AGFI} \leq 1,00$ & $0,85 \leq \mathrm{AGFI} \leq 0,90$ & 0,700 & 0,670 & 0,690 & 0,903 \\
\hline NFI & $0,95 \leq \mathrm{NFI} \leq 1,00$ & $0,90 \leq \mathrm{NFI} \leq 0,95$ & 0,740 & 0,700 & 0,700 & 0,912 \\
\hline CFI & $0,97 \leq \mathrm{CFI} \leq 1,00$ & $0,95 \leq \mathrm{NFI} \leq 0,97$ & 0,780 & 0,720 & 0,750 & 0,950 \\
\hline RMSEA & $0 \leq \mathrm{RMSA} \leq 0,05$ & $0,05 \leq \mathrm{RMSA} \leq 0,08$ & 0,102 & 0,110 & 0,100 & 0,078 \\
\hline
\end{tabular}

Tablo 3'e göre, ilişkisiz, ikincil seviye ve tek faktörlü doğrulayıcı faktör analizi modellerinin çoğu göstergeleri uyum iyiliğini sağlayamamıştır. Buna karşın, birincil seviye doğrulayıcı faktör analizi modelinin NFI değeri $(0,895)$ kabul edilebilir uyuma yakın, diğger göstergeler ise kabul edilebilir veya iyi uyum değerlerine sahip olduğu tespit edilmiştir. Bu anlamda birincil seviye doğrulayıcı faktör analizi için NFI değerinin yükseltilmesi için KİE4 (e4) ve KİE1 (e7) göstergelerine ait hata terimleri arasında modifikasyon işlemi yapılarak NFI değerinin kabul edilebilir uyum iyiliği değerinde olması sağlanmıştır (NFI=0,912).

Doğrulayıc faktör analizinde, bileşim ve ayrışım geçerliliğinin tespit edilmesi gerekmektedir. Bileşim ve ayrışım geçerliliği ile gözlenen değişkenlerin bağlı olduğu gözlenemeyen değişkenlerin ne derecede yansıttığı ölçülebilmektedir.

Bileşim ve ayrışım geçerliliğin tespiti için değişkenler arasındaki ilişki ile birleşik güvenirlik ve açıklanan ortalama varyans değerlerinin hesaplanması gerekmektedir (Büyükyılmaz ve Fidan, 2017: 512).

Bileşim geçerliliğin sağlanması için birleşik güvenirlik değerinin (CR) 0,500 değerinden ve açıllanan ortalama varyans değerinin (AVE) 0,700 değerinden büyük olmalıdır. Ayrıca CR değerinin AVE değerinden büyük olması gerekmektedir. 
Ayrışım geçerliliğin sağlanması için ise AVE değerlerinin karakök değerlerinin, faktörler arasındaki korelasyon değerlerinden büyüklüğü aranmaktadır (Fornell ve Larcker, 1981; Hair, Andersen, Tatham ve Black, 1998). Bu anlamda bileşim ve ayrışım geçerliliği kapsamında tespit edilen ölçümler Tablo 4'de açıklanmıştır.

Tablo 4. Bileşim ve Ayrışım Geçerliliği İçin Tespit Edilen Değerler

\begin{tabular}{|c|c|c|c|c|c|c|c|c|}
\hline Faktörler & Göstergeler & Ortalamalar & $\begin{array}{l}\text { Standart } \\
\text { Sapmalar }\end{array}$ & $\begin{array}{c}\text { Cronbabach } \\
\text { Alpha }\end{array}$ & CR & AVE & $\begin{array}{c}\text { AVE } \\
\text { Karakök }\end{array}$ & Korelasyon \\
\hline \multirow{7}{*}{$\begin{array}{c}\text { Küresel } \\
\text { İnovasyon } \\
\text { Endeksi }\end{array}$} & KİE1 & 57,0166 & 28,8100 & \multirow{9}{*}{0,830} & \multirow{7}{*}{0,940} & \multirow{7}{*}{0,561} & \multirow{7}{*}{0,74899} & \multirow{9}{*}{0,740} \\
\hline & KİE2 & 37,7260 & 19,3559 & & & & & \\
\hline & KİE3 & 40,6869 & 20,2833 & & & & & \\
\hline & KİE4 & 46,7256 & 23,2218 & & & & & \\
\hline & KİE5 & 35,4250 & 17,3711 & & & & & \\
\hline & KİE6 & 30,9737 & 17,5879 & & & & & \\
\hline & KİE7 & 33,0084 & 16,6497 & & & & & \\
\hline \multirow{2}{*}{$\begin{array}{c}\text { Ekonomik } \\
\text { Büyüme }\end{array}$} & $\begin{array}{c}\text { NOMINAL } \\
\text { GSYH }\end{array}$ & 69,0767 & 24,9358 & & \multirow[t]{2}{*}{0,790} & \multirow[t]{2}{*}{0,550} & \multirow{2}{*}{0,74162} & \\
\hline & REEL GSYH & 7,2864 & 7,87434 & & & & & \\
\hline
\end{tabular}

Tablo 4'e göre, küresel inovasyon endeksi ve ekonomik büyüme faktörlerine ait CR değerlerinin 0,500 değerinden ve faktörlere ait AVE değerlerinin ise 0,700 değerinden yüksek olduğu tespit edilmiştir. Bunun yanında faktörlere ait CR değerleri, AVE değerlerinden yüksek çıkmıştır. Ayrıca faktörlere ait açılanan ortalama varyans değerlerinin, faktörler arası korelasyondan büyük olduğu görülmüştür. Dolayısıyla oluşturulan modelin bileşim ve ayrışım geçerliliği sağlanmıştır.

Tablo 5. Faktörlerin ve Hata Terimlerin Varyanslarına Ait Değerler

\begin{tabular}{|c|c|c|c|c|}
\hline Faktörler ve Göstergeler & Varyans & Standart Hata & t & p \\
\hline Küresel İnovasyon Endeksi (KİE) & 23,256 & 6,862 & 8,86962 & $* * *$ \\
\hline Ekonomik Büyüme (EB) & 22,678 & 3,318 & 6,83484 & $* * *$ \\
\hline e1 $\rightarrow$ KİE7 & 37,633 & 4,112 & 9,15199 & $* * *$ \\
\hline e2 $\rightarrow$ KIE6 & 55,334 & 5,857 & 9,44749 & $* * *$ \\
\hline e3 $\rightarrow$ KİE5 & 26,061 & 3,086 & 8,44491 & $* * *$ \\
\hline e4 $\rightarrow$ KİE4 & 60,491 & 6,920 & 8,74147 & $* * *$ \\
\hline e5 $\rightarrow$ KİE3 & 32,666 & 3,949 & 8,27196 & $* * *$ \\
\hline e6 $\rightarrow$ KİE2 & 22,868 & 2,996 & 7,63284 & $* * *$ \\
\hline e7 $\rightarrow$ KİE1 & 57,890 & 7,290 & 7,94101 & $* * *$ \\
\hline e8 $\rightarrow$ Nominal GSYH & 59,678 & 6,532 & 9,13625 & $* * *$ \\
\hline e9 $\rightarrow$ Reel GSYH & 56,673 & 8,655 & 6,54800 & $* *$ \\
\hline
\end{tabular}

$$
* * *=\mathrm{p}<.01
$$


Tablo 5'de faktörlere ve göstergelere ait varyans değerleri belirtilmiştir. Tablo 4'e göre, faktörlerin ve göstergelerin varyans değerlerinin hepsi anlamlı olarak hesaplanmiştır $(* * *=p<.01)$.

Tablo 5'e göre, ekonomik büyüme faktörünün (gizil değişken) kendi göstergelerine (gözlemlenen değişkenler) ait varyans değeri, inovasyon faktörünün (gizil değişken) kendi göstergelerine (gözlemlenen değişkenler) ait varyans değerinden az çıkmıştır (Ekonomik Büyümevaryans=22,678 < Küresel İnovasyon Endeksi ${ }_{\text {Varyans }}=23,256$ ). Bu durum, ekonomik büyüme faktörünün (gizil değişken) kendi göstergelerine (gözlemlenen değişkenler) ait varyans yakınlığının, inovasyon faktörünün kendi göstergelerine olan varyans yakınlı̆̆ından fazla olduğunu göstermektedir.

Aynı şekilde Tablo 5'e göre, KİE2 göstergesinin varyans değerinin, diğer göstergelerin varyans değerlerine göre daha az olduğu tespit edilmiştir (KİE2 Varyans $=22,868<$ Diğer Göstergeler). Bu durum ise KİE2 göstergesinin kendi hata terimine olan varyans yakınlı̆̆ının, diğer göstergelerin kendi hata terimlerine ait varyans yakınlığından fazla olduğunu göstermektedir.

Tablo 6. Faktörler ve Göstergeler Arasındaki İlişki Değerleri

\begin{tabular}{|c|c|c|c|c|c|c|c|c|c|c|c|}
\hline Göstergeler & KİE & EB & $\begin{array}{c}\text { Reel } \\
\text { GSYH }\end{array}$ & $\begin{array}{c}\text { Nom. } \\
\text { GSYH }\end{array}$ & KİE1 & KİE2 & KİE3 & KİE4 & KİE5 & KİE6 & KIE7 \\
\hline KİE & 1 & & & & & & & & & & \\
\hline EB & $0,745^{*}$ & 1 & & & & & & & & & \\
\hline Reel GSMH & $0,760^{*}$ & $0,720^{*}$ & 1 & & & & & & & & \\
\hline $\begin{array}{c}\text { Nom. } \\
\text { GSMH }\end{array}$ & $0,725^{*}$ & $0,700^{*}$ & $0,754^{*}$ & 1 & & & & & & & \\
\hline KİE1 & $0,730^{*}$ & $0,657^{*}$ & $0,677^{*}$ & $0,617^{*}$ & 1 & & & & & & \\
\hline KIE2 & $0,710^{*}$ & $0,740^{*}$ & $0,679^{*}$ & $0,777^{* *}$ & $0,834^{*}$ & 1 & & & & & \\
\hline KİE3 & $0,760^{*}$ & $0,745^{*}$ & $0,776^{* *}$ & $0,716^{*}$ & $0,825^{*}$ & $0,829^{* *}$ & 1 & & & & \\
\hline KIE4 & $0,740^{*}$ & $0,755^{*}$ & $0,773^{* *}$ & $0,744^{*}$ & $0,856^{* *}$ & $0,813^{*}$ & $0,804^{*}$ & 1 & & & \\
\hline KIE5 & $0,760^{*}$ & $0,782^{*}$ & $0,780^{* *}$ & $0,785^{* *}$ & $0,822^{* *}$ & $0,826^{* *}$ & $0,817^{* *}$ & $0,800^{* *}$ & 1 & & \\
\hline KIE6 & $0,770^{* *}$ & $0,731^{*}$ & $0,766^{*}$ & $0,711^{*}$ & $0,773^{* *}$ & $0,777^{* *}$ & $0,769^{*}$ & $0,753^{*}$ & $0,765^{*}$ & 1 & \\
\hline KIE7 & $0,770^{* *}$ & $0,640^{*}$ & $0,670^{*}$ & $0,612^{*}$ & $0,796^{* *}$ & $0,800^{* *}$ & $0,791^{* *}$ & $0,775^{* *}$ & $0,788^{* *}$ & $0,742^{*}$ & 1 \\
\hline
\end{tabular}

Tablo 6'da faktörlerin ve göstergelerin birbirleri arasındaki korelasyon değerleri sunulmuştur. Tablo 6'ya göre, tüm faktörler ve göstergeler arasındaki korelasyon değerlerin pozitif yönlü ve anlamlı olduğu $\left({ }^{*}=p<.05, \mathrm{p}^{* *}=<.01\right)$ tespit edilmiştir. 
Tablo 6'ya göre, faktörler ve göstergeler arası değerlerin genel olarak yüksek düzeyde olduğu gözlenmiştir. Dolayısıyla bu durum, küresel inovasyon endeksinin, ekonomik büyüme faktörleri ile faktörlere ait göstergelerin birbirlerini tamamlayan bütünleşik bir yapıda olduğunu göstermektedir.

Şekil 2'de belirtilen modelin doğruluğunu tespit etmek ve buna göre inovasyon ile ekonomik büyüme arasındaki ilişkiyi ortaya koymak için yol analizi metodu uygulanmıştır. Bu kapsamda oluşturulan modele ilişkin yol analizi diyagramı Şekil 3'de belirtilmiştir.

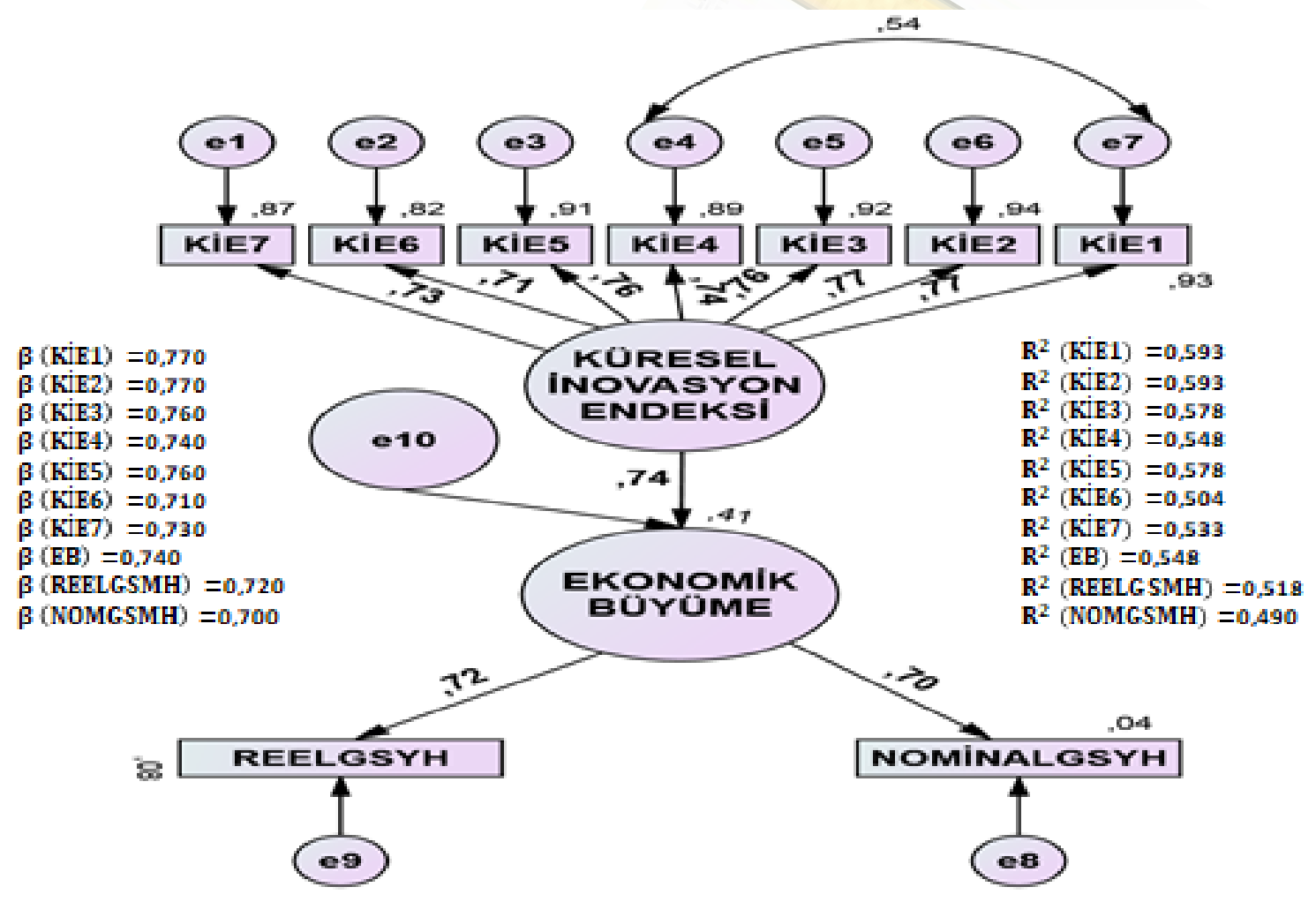

Şekil 3. Modele Göre Oluşturulan Yol Analizi Diyagramı

Birincil seviye doğrulayıcı faktör analizi modeli, faktörler (gizil değişkenler) arasında ilişki yapısını açıklamaktadır. Dolayısıyla Şekil 3'de gösterilen yol analizi yine söz konusu faktörler arasındaki ilişki modelini (etki değerini) açıkladığ analizin uyum iyiliği değerleri ile birincil seviye doğrulayıcı faktör analizinin uyum iyiliği değerleri aynı çıkmıştır. Buna göre, yol analizinde uyum iyiliği sağlamak için Tablo 3'de belirtilen modifikasyon öncesinde birincil seviye doğrulayıcı faktör analizinde NFI değerinin kabul edilebilir uyum seviyesine getirmek amacıyla KİE4 (e4) ve KİE7 (e7) göstergeler arasındaki modifikasyon işleminin aynısı yapılmıştır. 
Buna bağlı olarak oluşturulan yol analizinin uyum iyiliği değerleri, Tablo 3'de birincil seviye doğrulayıcı faktör analizi kapsamında tespit edilen uyum iyiliği değerlerini belirtmektedir.

Yol analizinde standart olmayan regresyon değerleri ile faktörlerin (gizil değişkenlerin) değişiminin faktörlerin etkilediği göstergelerde (gözlemlenen değişkenlerde) ve diğer faktörlerde nasıl bir değişim oluşturduğunun tespiti yapılabilmektedir. Buna göre, standart olmayan regresyon değerleri ile faktörler arasında ve faktörlerin etkilediği göstergeler arasında doğrusal denklemler oluşturulabilmektedir. Başka bir ifade ile yol analizinde standart olmayan regresyon değerleri, göstergelerin (gözlemlenen değişkenlerin) faktörlere veya bağımlı değişken olan faktörün etkilediği bağımsız değişken faktörüne göre türevini belirtmektedir. Bu çerçevede oluşturulan modele göre tespit edilen standart olmayan değerler ve değerlere göre oluşturulan denklemler Tablo 7' de açıklanmıştır.

Tablo 7. Standart Olmayan Regresyon Değerleri

\begin{tabular}{|c|c|c|c|c|c|c|}
\hline \multicolumn{2}{|c|}{ İçsel Gözlenebilen Değişkenler } & \multirow{2}{*}{$\begin{array}{c}\text { Gizil Değişkenler } \\
\text { KİE }\end{array}$} & \multirow{2}{*}{$\begin{array}{c}\begin{array}{c}\text { Std. } \\
\text { Olmayan } \\
\text { Reg. Değeri }\end{array} \\
0,620\end{array}$} & \multirow{2}{*}{$\begin{array}{c}\text { Standart Hata } \\
0,033\end{array}$} & \multirow{2}{*}{$\begin{array}{c}\mathbf{t} \\
18,788 \\
\end{array}$} & \multirow{2}{*}{ p } \\
\hline EB & $\leftarrow$ & & & & & \\
\hline KİE1 & $\leftarrow$ & KİE & 0,674 & 0,049 & 13,755 & $* * *$ \\
\hline KİE2 & $\leftarrow$ & KİE & 0,613 & 0,032 & 19,156 & $* * *$ \\
\hline KIE3 & $\leftarrow$ & KİE & 0,672 & 0,035 & 19,2 & *** \\
\hline KİE4 & $\leftarrow$ & KİE & 0,680 & 0,044 & 15,455 & $* * *$ \\
\hline KİE5 & $\leftarrow$ & KİE & 0,720 & 0,042 & 17,143 & $* * *$ \\
\hline KIE6 & $\leftarrow$ & KİE & 0,660 & 0,038 & 17,368 & *** \\
\hline KİE7 & $\leftarrow$ & KİE & 0,632 & 0,033 & 19,152 & *** \\
\hline NOMINALGSYH & $\leftarrow$ & EB & 0,730 & 0,153 & 4,7712 & *** \\
\hline REELGSYH & $\leftarrow$ & EB & 0,740 & 0,245 & 3,0204 & $* * *$ \\
\hline \multicolumn{7}{|c|}{ Denklemler } \\
\hline EB & $\leftarrow$ & KİE & \multicolumn{4}{|c|}{$\mathrm{EB}=\mathrm{KİE} \cdot 0,620+\mathrm{e} 10$} \\
\hline KIE1 & $\leftarrow$ & KİE & \multicolumn{4}{|c|}{ KİE1=KİE.0,674+e7 } \\
\hline KIE2 & $\leftarrow$ & KIE & \multicolumn{4}{|c|}{ KIE2=KIE.0,613+e6 } \\
\hline KIE3 & $\leftarrow$ & KİE & \multicolumn{4}{|c|}{ KİE3=KİE.0,672+e5 } \\
\hline KIE4 & $\leftarrow$ & KİE & \multicolumn{4}{|c|}{ KIE4=KIE.680+e4 } \\
\hline KIE5 & $\leftarrow$ & KİE & \multicolumn{4}{|c|}{ KİE5=KİE.0,720+e3 } \\
\hline KİE6 & $\leftarrow$ & KIE & \multicolumn{4}{|c|}{ KİE6=KİE.0,660+e2 } \\
\hline KİE7 & $\leftarrow$ & KİE & \multicolumn{4}{|c|}{ KİE7=KIE.0,632+e1 } \\
\hline NOMINALGSYH & $\leftarrow$ & EB & \multicolumn{4}{|c|}{ NOMINALGSYH=KİE.0,730+e8 } \\
\hline REELGSYH & $\leftarrow$ & EB & \multicolumn{4}{|c|}{ REELGSMH=KİE.0,740+e9 } \\
\hline
\end{tabular}


Tablo 7’ye göre, faktörlerin kendisine bağlı faktörler ile olan etkisel yapıların tümü pozitif yönlü ve anlamlı $\left({ }^{* * *}=p<.01\right)$ olduğu tespit edilmiştir. Tablo 7 değerlendirildiğinde, küresel inovasyon endeksinde bir birimlik artış sırasıyla KİE5' de 0,720, KİE4'de 0,680, KİE1'de 0,674, KİE3'de 0,672, KİE6'da 0,660, KİE7'de 0,632, EB' de 0,620, KİE2' de 0,613 değerinde bir artış meydana getirmiştir. Değerlere göre, küresel inovasyon endeksinin kendisine bağlı göstergeler arasındaki artış oranları arasında anlamlı farklılıklar bulunmamaktadır. Ayrıca küresel inovasyon endeksinin ekonomik büyümeyi etkilemesine göre en hassas gösterge KİE5 (iş gelişmişliği) olduğu tespit edilmiştir. Diğer bir ifade ile bu durum, G20 ülkelerinin inovasyon faaliyetleri ile inovasyonun ekonomik büyümeyi etkilemesinde KİE5 (iş gelişmişliği) göstergesinin küresel inovasyon endeksini oluşturan diğer göstergelere göre değişime uğrama ivmesinin ve esneklik katsayısının daha fazla olduğunu göstermektedir. Bunun nedeni olarak G20 ülkelerinin iş gelişmişliği kapsaminda yaptıkları faaliyetlerin (kalifiyeli çalışanları artırma, çalışanların uzmanlaşması, çalışanların yenilik bağlantılarını kurması) ekonomik büyüme için yapılan faaliyetleri sağlamasından kaynaklandığı değerlendirilebilir.

Tablo 7'ye göre, küresel inovasyon endeksi boyutunun ekonomik büyümeyi etkilemesinde ekonomik büyümede meydana gelen bir birimlik artış sirasıyla reel GSYH'y1 0,740, nominal GSYH'y1 0,730 birim etkilemektedir. Dolayısıla bu durum, G20 ülkelerinin inovasyon faaliyetleri reel GSYH'yı nominal GSYH'ya göre daha fazla nitelikli olarak değişime uğratmaktadır. Aslında bu durum beklenen bir sonuçtur. Çünkü reel GSMH yıllara göre nominal GSYH oransal anlamda değişimini açıklamaktadır. 
Tablo 8. Standart Regresyon Ağırlıkları

\begin{tabular}{|c|c|c|c|}
\hline \multicolumn{2}{|c|}{ EB ve Göstergeler } & \multirow{2}{*}{$\begin{array}{c}\text { Faktörler (Gizil Değişkenler) } \\
\text { KÜRESEL İNOVASYON ENDEKSİ }\end{array}$} & \multirow{2}{*}{$\frac{\text { Değer }}{\gamma_{\text {Kï } \rightarrow \text { EB }}=0,740}$} \\
\hline EKONOMİK BÜYÜME & $\leftarrow$ & & \\
\hline KİE1 & $\leftarrow$ & KÜRESEL İNOVASYON ENDEKSİ & $\beta_{\mathrm{KIE} \rightarrow \mathrm{KIE} 1}=0,770$ \\
\hline KİE2 & $\leftarrow$ & KÜRESEL İNOVASYON ENDEKSİ & $\beta_{\mathrm{KIE} \rightarrow \mathrm{KIE} 2}=0,770$ \\
\hline KIE3 & $\leftarrow$ & KÜRESEL İNOVASYON ENDEKSİ & $\beta_{\mathrm{KIE} \rightarrow \mathrm{KIE} 3}=0,760$ \\
\hline KİE4 & $\leftarrow$ & KÜRESEL İNOVASYON ENDEKSİ & $\beta_{\mathrm{KIE} \rightarrow \mathrm{KIE} 4}=0,740$ \\
\hline KİE5 & $\leftarrow$ & KÜRESEL İNOVASYON ENDEKSİ & $\beta_{\mathrm{KIE} \rightarrow \mathrm{KIE} 5}=0,760$ \\
\hline KİE6 & $\leftarrow$ & KÜRESEL İNOVASYON ENDEKSİ & $\beta_{\mathrm{KiE} \rightarrow \mathrm{KiE} 6}=0,710$ \\
\hline KİE7 & $\leftarrow$ & KÜRESEL İNOVASYON ENDEKSI & $\beta_{\mathrm{KIE} \rightarrow \mathrm{KiE7}}=0,730$ \\
\hline NOMINAL GSYH & $\leftarrow$ & EKONOMIKK BÜYÜME & $\beta_{\mathrm{EB} \rightarrow \mathrm{NOMINALGSMH}}=0,700$ \\
\hline REEL GSYH & $\leftarrow$ & EKONOMİK BÜYÜME & $\beta_{\text {EB } \rightarrow \text { REELGSMH }}=0,720$ \\
\hline
\end{tabular}

Standart regresyon ağırlıkları bağımsız değişkenin standart sapmasında bir birimlik değişimin bağımlı değişkenin standart sapmasını ne kadar değiştirdiğini göstermektedir. Dolayısıyla standart katsayılar, faktörlerin (gizil değişkenlerin) birbirlerini etki değerlerini ve bağımsız değişkenler (gizil değişkenler, faktörler) için bağımlı değişkenlerin (gözlemlenen değişkenler, göstergeler) önemlilik değerlerini (etkisel yapıya katkı değerlerini) belirtmektedir. Tablo 8'e göre, küresel inovasyon endeksi ekonomik büyümeyi pozitif yönde ve yüksek değerde etkilediği için $(\gamma$ KiE $\rightarrow \mathrm{EB}=0,740)$ oluşturulan model doğrulanmıştır.

Tablo 8 değerlendirildiğinde, faktörler kendisine ait göstergeleri yüksek derecede etkilemişlerdir. Küresel inovasyon endeksi faktörünün kendi göstergelerini etkileme değerleri, göstergelerin etkisel yapıya katkı değerleri veya küresel inovasyon endeksi için göstergelerin önemlilik değerleri KİE1 ve KİE2 $\left(\beta_{\mathrm{KIE} \rightarrow \mathrm{KIE} 1}=0,770, \beta_{\mathrm{KIE} \rightarrow \mathrm{KIE} 2}=0,770\right), \mathrm{KI} 3$ ve KİE$\left(\beta_{\mathrm{KIE} \rightarrow \mathrm{KIE} 3}=0,760, \beta_{\mathrm{KIE} \rightarrow \mathrm{KIE} 5}=0,760\right), \mathrm{KIEE} 4$ $\left(\beta_{\text {KIE } \rightarrow \text { KIE } 4}=0,740\right), \quad$ KIE7 $\quad\left(\beta_{\text {KIE } \rightarrow \text { KIE7 }}=0,730\right)$ ve KIE6 $\quad\left(\beta_{\text {KIE } \rightarrow \text { KIE6 }}=0,710\right) \quad$ olarak sıralanmıştır. Ekonomik büyüme faktörünün göstergeleri etkileme değerleri ise reel GSYH $\left(\beta_{\text {EB } \rightarrow \text { REELGSMH }}=0,720\right)$ ve nominal GSYH $\left(\beta_{\text {EB } \rightarrow \text { NOMINALGSMH }}=0,700\right)$ olarak sıralanmıştır. Bulgulara göre, G20 ülkeleri açısından küresel inovasyon endeksinin ekonomik büyümeyi etkilemesiyle Kie3, Kie4, Kie5, Kie6 ve Kie7 göstergeleri Kie1 ve Kie2 göstergelerin performanslarını artırmış ve onları nitelikleştirmiştir. Buna bağlı olarak G20 ülkeleri için Kie1 ve Kie2 göstergelerin bütünsel anlamda küresel inovasyon endeksi için küresel inovasyonun ekonomik büyümeyi etkilemesinde 
anlamlılıklarının, önemliliklerinin ve önceliklerinin diğer göstergelere göre daha fazla olduğunu göstermektedir.

\section{SONUÇ VE TARTIŞMA}

Çalışmanın literatür kısmında; inovasyon, küresel inovasyon endeksi, ekonomik büyüme, inovasyon boyutu ile ekonomik büyüme arasındaki ilişki ile inovasyon ve ekonomik büyüme arasındaki ilişkiyi ele alan çalışmalar açıklanmıştır. Araştırmanın amacı, literatür destekli oluşturulan inovasyon boyutunun ekonomik büyümeyi etkilemesi modeli kapsamında inovasyon boyutunun ekonomik büyümeye olan etki değerini, inovasyon boyutunun ekonomik büyümeyi etkilemesinde en hassas göstergeyi (değişkeni) ve göstergelerin önemlilik değerlerini (etkisel yapıya katkı değerlerini) tespit etmektir.

Araştırmada ilk olarak modelin yapıya uygunluğunu test etmek için doğrulayıcı faktör analizi uygulanmıştır. Söz konusu yapıya en uygun olan doğrulayıcı faktör analizinin birincil seviye doğrulayıcı faktör analizi olduğu değerlendirilmiştir. Bulgulara göre, inovasyon boyutunun (küresel inovasyon endeksi) ekonomik büyümeyi yüksek derecede etkilediği ve oluşturulan modelin doğrulandığ̣ görülmüştür. Araştırmada G20 ülkeleri için inovasyon boyutunun ekonomik büyümeyi etkilemesinde en hassas göstergenin Kie5 olduğu sonucuna varılmıştır. Çünkü inovasyon boyutunun ekonomik büyümeyi etkilemesiyle, inovasyon boyutundaki birim değişme Kie5 inovasyon göstergesini diğer inovasyon göstergelerine kıyasla daha fazla değiştirdiği tespit edilmiştir. Bunun nedeni, G20 ülkelerinin Kie5 ile ilgili uygulamaları kapsamında yapmış oldukları nitelikli çalışanlar oluşturma (bilgi donanımlı yoğun hizmet servisleri sağlama), inovasyon oluşturma (yenilik ă̆ sistemlerini kurma, üniversitelerin bilgi üretmesi, patent oluşturma, girişimcilik ve stratejik faaliyetler să̆lama), bilgi yoğunlaşması (araştırmalara uygun ödenek sağlanması, teknoloji ihracatı, bilgi kullanımını sıklaştırma, yabancı yatırımları sağlama, iş girişimlerinde araştırma yeteneklerinden faydalanma) faaliyetlerinin ekonomik büyümeyi sağlayacak bir yapıya kavuşturmuş olmalarından kaynaklandığı değerlendirilebilir. Buna bağlı olarak G20 ülkeleri, 
öncelikli olarak ekonomik büyümenin sağlanmasında temel anlamda ekonomik kalkınmanın temellerinden biri olan iş gelişmişliğine daha çok yoğunlaşmışlardır.

G20 ülkelerine göre, inovasyon boyutunun ekonomik büyümeyi etkilemesinde en önemli inovasyon göstergeleri Kie1 ve Kie2 olduğu tespit edilmiştir. Çünkü G20 ülkelerine göre, Kie1 ve Kie2 inovasyon göstergeleri ekonomik büyümedeki nitelikli değişimi daha fazla oluşturmuş ve söz konusu göstergelerin ekonomik büyümeyi etkilemesinde ve sağlamasında diğer inovasyon göstergelerine göre daha fazla katkı sağlamışlardır. Bu anlamda G20 ülkelerinin ekonomik büyümeyi sağlamalarında Kie1 (kurumlar: politik çevre, düzenleyici çevre ve iş çevresi) ve Kie2 (Beşeri Sermaye ve Araştırma: Eğitim, yüksek öğretim, araştırma ve geliştirme) inovasyon göstergeleri diğer inovasyon göstergelerine göre ekonomik büyümenin daha fazla nitelikli değişimini sağlayarak ekonomik büyümedeki mevcut düzenin ve istikrarın farklı bir düzen ve istikrar haline almasını sağlamışlardır. Dolayısıyla G20 ülkeleri, ekonomik büyüme öz yapısının değişmesinde, Kie1 ve Kie2 inovasyon göstergelerine diğer inovasyon göstergelerine göre daha fazla önem vermişlerdir. Bu durum, söz konusu göstergelerin diğer inovasyon göstergelerine göre daha temel ve öncelikli yapılarının olmalarından kaynaklanabilir.

Araştırma inovasyon ve ekonomik büyümeyi anlamlı ve pozitif yönde etkilemesi çerçevesinde literatürde belirtilen Shukla (2017) hariç diğer araştırmacıların sonuçları ile tutarlılık göstermiştir. Bu çerçevede bu çalışma, tespit edilen diğer araştırmalar gibi inovasyonun ekonomik büyümeyi sağladığına yönelik ampirik bulgular kapsamında literatüre katkı sağlamıştır.

G20 ülkeleri inovasyon göstergeleri arasındaki ilişkileri ve tamamlayıcılık faaliyetlerini artırarak ekonomik büyüme ile ekonomik büyümenin istikrarının ve düzeninin oluşmasını daha çok sağlayabilirler. Buna göre G20 ülkeleri, öncelikli olarak diğer inovasyon göstergelerine göre standart regresyon ağırlıkları az olan Kie6, Kie7 ve Ki4 ve diğer inovasyon göstergelerinin birbirlerini ve ekonomik boyutu ilgilendiren konulardaki nitelikli faaliyetlerini artırarak ve ilgili inovasyon göstergelerine önem vererek inovasyonun ekonomik büyüme üzerindeki yüksek 
etkisini daha yüksek seviyelere çıkarabilirler. Böylelikle G20 ülkeleri, inovasyon konusunda daha yoğun çalışmaları, inovasyon konusunda uzmanlaşmalarının ve inovasyon sistemlerinin, stratejilerinin, yöntemlerinin ve uygulamalarının daha sağlıklı olmasını sağlayabileceklerdir. Bu anlamda inovasyon boyutu, sadece ekonomik büyümenin değil, ekonomik büyümenin doğrudan etkilediği farklı (ekonomik kalkınma, rekabet üstünlüğü sağlama, ekonomik gelişmişlik) ve dolaylı olarak etkilediği alanların (bilim, teknik, sanat, spor, tıp, yaşam kalitesi, refah düzeyi, yaşam standardı) sağlıklı olarak gelişmelerinde katkıda bulunabilecektir.

G20 grubu ülkeleri haricinde diğer ülkeler, genel anlamda ekonomik büyümelerini sağlamaları için ilk olarak inovasyon göstergeleri arasındaki ilişkisel yapıyı pozitif yönde artırıcı faaliyetler yapmalıdırlar. Sonrasında ülkeler, tıpkı G20 ülkeleri gibi inovasyon boyutunun ekonomik büyümeyi etkilemesinde temel ve öncelikli yapısı bulunan Kie1 ve Kie2 inovasyon boyutlarının diğer inovasyon göstergelerinin performasını geliştirecek ve ekonomik büyümeyi ilgilendirecek faaliyetler oluşturabilirler.

Araştırmacılar için ülkelerin inovasyon performanslarını ölçen diğer endeks veya metriklerden yararlanarak inovasyon boyutunun ekonomik boyutu üzerindeki etkileri karşılaştırmaları önerilebilir. Böylelikle ekonomik büyüme için inovasyon göstergelerin niteliği nedensellik analizleri çerçevesinde tartışılabilir. Ayrıca ülkelerin inovasyon performansının ölçülmesinde göstergelerin sayısı artırılabilir ya da her ülkeye özgü göstergeler oluşturulabilir. Böylelikle ülkelerin inovasyon konusundaki yetenekleri, kapasiteleri ve potansiyelleri çok boyutlu olarak değerlendirilerek inovasyonun ekonomik büyümeye olan etkisinin tespit edilmesinde daha gerçekçi sonuçlara ulaşılabilir. 


\section{KAYNAKÇA}

Acaravcı Kekilli, S., Ural, T. ve Karaömer, Y. (2018). Hisse senedi getirisi ve sermaye yapısı ilişkisine etki eden faktörlerin yapısal eşitlik modelleme ile analizi. İşletme ve İktisat Çalışmaları Dergisi, 6(4), 2638.

Aghion, P. ve Howitt, P. (1992). A model of growht through creative destruction. Econometrica, 60(2), 323-351.

Akça, H. S. (2018). Ekonomik büyüme ve inovasyon ilişkisi. Yayımlanmamış Yüksek Lisans Tezi, KTO Karatay Üniversitesi, Sosyal Bilimler Enstitüsü, Konya.

Aktuğ, S. (2010). Kavramsal açıdan ekonomik büyüme, ekonomik kalkınma ve bölüşüm ilişkileri. (Eylül 2020 tarihinde www.sosyalpolitikainfo.files.wordpress.com adresinden alındı).

Alataş, S. (2014). Ekonomik kalkınmayı belirleyen faktörler: Ampirik bir analiz, Yayımlanmamış Yüksek Lisans Tezi, Adnan Menderes Üniversitesi Sosyal Bilimler Enstitüsü, Aydın.

Aras, G., Tezcan, N., Kutlu Furtuna, Ö. ve Aybars, A. (2014). Firmalarn Ar-Ge ve inovasyon performansının stratejik analizi. İstanbul: İstanbul Ticaret Odası Özkaracan Matbaacılık.

Ay Türkmen, M., ve Aynaoğlu, Y. (2017). Küresel rekabet endeksi göstergelerin küresel inovasyon üzerine etkisi. Business \& Management Studies: An International Journal, 5(4), 257-282.

Aydoğdu, A. (2013). Örgüt kültürünün inovasyon yapısına etkisi ve bir araştırma, Yayımlanmamış Yüksek Lisans Tezi, Marmara Üniversitesi Sosyal Bilimler Enstütüsü, İstanbul.

Ballı, E. (2017). Teknoloji, inovasyon ve ekonomik büyüme ilişkisi: Üst ve üst orta gelir gruplarındaki ülkeler üzerine bir inceleme. Ekonomi Bilimleri Dergisi, 9(2), 15-28.

Ballı, E. ve Güreşçi, G. (2017). İnovasyon ve ekonomik büyüme: Üst ve üst-orta gelirli ülkeler örneği. Yönetim ve Ekonomi Araştırmaları Dergisi, Özel Sayı 1, 99-112.

Barro, H. J. (1990). Goverment spending in the simple model of endogenous growht. The Journal of Political Economy, 98(5), 103-125.

Başer, F. ve Gökten, S. (2019). Paths of economic development: A global evidence for the mediating role of human capital. The Journal of International Trade \& Economic Development, 28(8), 996-1018.

Bilir, B. Ö. ve Gökdemir, T. (2018). Kalkınma göstergeleri çerçevesinde yaşam beklentisinin yapısal eşitlik modeli ile incelenmesi. Anemon Muş Alparslan Üniversitesi Sosyal Bilimler Dergisi, Özel Sayı, 163167.

Bozan, T. (2019). İnovasyon ve ekonomik büyüme ilişkisi: G7 ülkeleri üzerine ekonometrik bir analiz, Yayımlanmamış Yüksek Lisans Tezi, Hasan Kalyoncu Üniversitesi, Sosyal Bilimler Enstitüsü, İstanbul. 
Brouwer, M. T. (2000). Entrepreneurship and uncertaintly: Innovation and competition among the many. Small Business Economics, 15(2), 149-160.

Burmaoğlu, S. (2012). Ulusal inovasyon göstergeleri ile ulusal lojistik perofrmansı arasındaki ilişki: AB ülkeleri üzerine bir araştırma. Ege Akademik Bakış, 12(2), 193-208.

Büyükyılmaz, O. ve Fidan, Y. (2017). Algılanan örgütsel desteğin örgütsel vatandaşlık davranış1 üzerindeki etkisinde örgütsel güvenin aracllık rolü. Business $\mathcal{E}$ Management Studias: An International Journal, 5(3), 500-524.

Cainelli, G., Evangelista, R. ve Savona, M. (2004). The impact of innovation on economic performance in services. The Service Industries Journal, 24(1), 116-130.

Cameron, G. (1996). Innovation and economic growth. London: Centre for Economic Performance London School of Economics and Political Science.

Capello, R. ve Lenzi, C. (2012). Knowledge, innovation and economic growth: Spatial heterogeneity in Europe.

Cesaratto, S. (1999). Savings and economic growth in neoclassical theory. Cambridge Journal of Economics, 23, 771-793.

Cornell University, INSEAD ve WIPO. (2019). Global Inovation Index Report (2019).

Çimen, A. ve Sağlam, Y. (2019). Ar-Ge harcamalarının sektörel performansının karşılaştırılması: İnovasyona dayalı ekonomik büyüme analizi. Journal of Yasar University, Special Issue, 58-68.

Dal, M. M. ve Yıldız, B. (2016). BRICS-TM ülkelerinde AR-GE ve inovasyonun ekonomik büyüme üzerine etkisi: Ekonometrik bir analiz. Akdeniz Üniversitesi İktisadi ve İdari Bilimler Fakültesi Dergisi, 33, 220-236.

Didero, M., Gareis, K., Marques, P. ve Ratzke, M. (2008). İnovasyon kültürünün hizmet inovasyonu performansına etkisi: Bitlis ili hizmet sektöründe bir araştırma. Atatürk Üniversitesi İktisadi ve İdari Bilimler Dergisi, 32(2), 351-366.

Drucker, P. F. (2002). The discipline of innovation, Harvard Business Review.

Elverdi, S. ve Atik, H. (2020). Girişimcilik ve ekonomik büyüme: Avrupa ve Kuzey avrupa ülkeleri üzerine bir uygulama. Uluslararası Sosyal Araştırmalar Dergisi, 13(69), 1170-1179.

Esmer, Y., Yüksel, M. ve Şaylan, O. (2019). Yerel yönetimlerde inovasyon uygulamalarına yönelik bir değerlendirme. Hukuk ve İktisat Araştırmaları Dergisi, 11(2), 175-189.

Evcim, N. (2017). AR-GE ve inovasyon faaliyetleri ile büyüme ilişkisi, Yayımlanmamış Yüksek Lisans Tezi, Pamukkale Üniversitesi Sosyal Bilimler Enstitüsü, Denizli.

Fagerberg, J., Srholec, M. ve Verspagen, B. (2009). Innovation and economic development. The Working Papers on Innovation Studies, 20090723, 1-62. 
Fornell, C. ve Larcker, D. F. (1981). Evaluating structural equation models with unobservable variables and measurement error. Journal and Marketing Research, 18(1), 39-50.

Galindo, M. A. ve Mendez, M. T. (2014). Entrepreneurship, economic growth, and innovation, are feedback effects at work ? Journal of Business Research, 67(5), 825-829.

Gerguri, S., ve Ramadani, V. (2010). The impact of innovation into the economic growht. Munich Personal RePEc Archive, 22270, 1-21.

Giunchiglia, F. (2013). Innovatione sociale la fuora frontiora. Department Information Engineering and Computer Science, DISI - Via Sommarive 5 - 38123 Povo. Trento: University of Trento.

Grossman, G. M. ve Helpman, E. (1991). Inovation and growht in the global economy. Massachusetts: Massachusetts Institute of Technology.

Gülmez, A. ve Akpolat, A. G. (2014). AR-GE inovasyon \& ekonomik büyüme. AİBÜ Sosyal Bilimler Enstitüsü Dergisi, 14(2), 1-17.

Hair, J. F., Black, W. C., Babin, B. J. ve Anderson, R. (1998). Multivariate data analysis. Essex: Pearson Education.

Hancıoğlu, Y. (2016). Küresel inovasyon endeksini oluşturan inovasyon girdi ve çıtı göstergeleri arasındaki ilişkinin kanonik korelasyon ile incelenmesi:OECD örneği. AİBÜ Sosyal Bilimler Enstitüsü Dergisi, 16(4), 131-157.

Hunady, J., ve Orviska, M. (2014). The impact of research and development expenditures on innovation pereformance and economic growht of the country-the empirical evidence. $C B U$ International Conference on Innovation, Technology Transfer and Education, Prague, 119-125.

INSEAD. (2007). The world's top innovators. France: The world business/INSEAD Global Innovation Index.

INSEAD and WIPO. (2011). Global inovation index report (2011).

Işık, N. (2017). Banka Kredisi, İnovasyon, Ekonomik Büyüme İlşkilerinin Analizi: G20 Örneği. Bankacalık ve Sermaye Piyasa Araştırmalan Dergisi, 1(2), 53-66.

Işık, N. ve Kılınç, e. c. (2012). inovasyon-güdümlü kalkınma: Avrupa Birliği ülkeleri ve türkiye Üzerine Bir İnceleme. Girişimcilik ve İnovasyon Yönetimi Dergisi, 1(1), 31-68.

Jankowska, B., Matysek, A., Jedrych, K. ve Mroczek, D. (2017). Efficiency of national innovation systems - Poland and Bulgaria in the context of the global innovation index. Comparative Economic Research, 20(3), 77-94.

Karaata, E. S. (2012). İnovasyonun ölçümünde yeni arayışlar. İstanbul: TÜSİAD-Sabancı Üniversitesi Rekabet Forumu. 
Kılıç, F. (2018). Açık inovasyon kavramı ve etkileri üzerine bir uygulama, Yayımlanmamış Yüksek Lisans Tezi, Pamukkale Üniversitesi Sosyal Bilimler Enstitüsü, Denizli.

Lucas, R. E. (1988). On the mechanics of economic development. Journal of Monetary Economics, 22, 342.

Maradana, R. P., Pradhan, R. P., Dash, S., Gaurav, K., Jayakumar, M. ve Chatterjee, D. (2017). Does innovation promote economic growth? evidence from European countries. Journal of Innovation and Entrepreneurship, 6(1), 1-23.

Marquis, D. G. (1969). The anotomy of successfull innovation. Innovation, 1, 28-37.

Meydan, C. H. ve Şeşen, H. (2015). Yapısal eşitlik modellemesi amos uygulamaları. Ankara: Detay Yayıncilik.

Mytelka , L. ve Farinelli, F. (2000). Local clusters, innovation systems and sustained competitiveness. Maastricht: United Nations University, Institute for New Technologies.

OECD ve Eurostat. (2005). Oslo klavuzu: Yenilik verilerinin toplanması ve yorumlanması için ilkeler, Ankara: TÜBITAK.

Özel, H. A. (2012). Ekonomik büyümenin teorik temelleri. Çankın Karatekin Üniversitesi İktisadi ve İdari Bilimler Fakültesi Dergisi, 2(1), 63-72.

Özkul, G. ve Örün, E. (2016). Girişimcilik ve inovasyonun ekonomik büyüme üzerindeki etkisi: Ampirik bir araştırma. Girişimcilik ve İnovasyon Yönetimi Dergisi, 5(2), 17-51.

Özyakışır, D. (2011). Beşeri sermayenin ekonomik kakınma sürecindeki rolü: Teorik bir değerlendirme. Girişimcilik ve Kalkınma Dergisi, 6(11), 46-71.

Pece, A. M., Simona, O. E. ve Salisteanuc, F. (2015). Innovation and economic growth: An empirical analysis for CEE countries. Procedia Economics and Finance, 26, 461-467.

Pessoa, A. (2007). Innovation and economic growth: What is the actual importance of R\&D ? FEP Working Papers, 254, 1-19.

Porter, M. (1990). Competitive advantage of nations, Harvard Business Review, 73-91.

Prasetyo, E. P. (2019). Role of entrepreneurial culture as the driver of economic growth. International Journal of Economics and Financial Issues, 9(3), 237-243.

Roberta, C. ve Camilla, L. (2013). Territorial patterns of innovation and economic growth in European regions. Growth and Change, 44(2), 195-227.

Romer, P. (1986). Increasing returns long-run growth. Journal of Political Economy, 94, 1002-1037.

Rosenberg, N. (2004). Innovation and Economic Growht. Organization for economic cooperation and development, Unpublisched Working Paper, 1-6. 
Schumpeter, J. (1934). The theory of economic development: an inquiry into profits, capital, credit, interest, and the business cycle. Harvard University Press: Cambridge.

Schumpeter, J. A. (1943). Capitalism, socialism, and democracy. London and New York: George Allen \& Unwin.

Shukla, S. (2017). Innovation and economic growth: A Case of India. Humanities \& Social Science Reviews, $5(2), 64-70$.

Siverekli Demircan, E. (2003). Vergilendirmenin ekonomik büyümeye ve kalkınmaya etkisi. Erciyes Üniversitesi İktisadi ve İdari Bilimler Fakültesi Dergisi, 21, 97-116.

Solow, R. M. (1956). A Contribution to the Theory of economic growth. The Quarterly Journal of Economic, 70(1), 65-94.

Soylu, A., Ceylan, S. ve Özdipçiner, N. S. (2019). Turizmde deneyim inovasyonu: Doğu ekspresi örneği. SETSCI Conference Proceedings, 4(8), 231-235.

Szirmai, A., Naudé, W. ve Goedhuys, M. (2011). Entrepreneurship, innovation, and economic development: An Overview. Oxford: Oxford University Press.

Şahinoğlu, K. T. ve Yakut, S. G. (2019). Yapısal eşitlik modeli ile özgürlüklerin ekonomik performansa etkisi üzerine bir inceleme. Ekoist: Journal of Econometrics and Statistics, 30, 1-20.

Şimşit, Z. T., Arığlu Akan, Ö. M., Saniye, Ü. ve Fırat, O. (2014). Küresel rekabet ve inovasyon çerçevesinde Türkiye'nin lojistik performansının değerlendirilmesi . 3. Ulusal Lojistik ve Tedarik Zinciri Kongeresi, Trabzon, 1-10.

Taş, S. (2017). İnovasyon, eğitim ve küresel inovasyon endeksi. Bilge Uluslararası Sosyal Araştırmalar Dergisi, 1(1), 99-123.

Tebaldi, E. ve Elmslie, B. (2008). Institutions, innovation and economic growth. Munich Personal RePEc Archive, 9683, 1-32.

Thompson, M. (2018). Social capital, innovation and economic growt. Journal of Behavioral and Experimental Economics, 73, 46-52.

Tunçbilek, M. M. ve Bayrakçı, S. (2017). Üniversitelerde algılanan liderlik, vizyon ve örgüt yapısının inovasyon yönetimine etkisi: Karabük Üniversitesi örneği. İstanbul Üniversitesi İşletme Fakültesi Isşletme İktisadı Enstitüsü Yönetim Dergisi, 28(83), 49-84.

Uca, N. (2016). Ülkelerin yolsuzluk algısının, lojistik performansının, dış ticaret hacminim ve küresel rekabet ilişkisinin yapısal eşitlik modeli ile incelenmesi: Kavramsal model önerisi, Yayımlanmamış Doktora Tezi, Maltepe Üniversitesi, Sosyal Bilimler Enstitüsü, İstanbul.

Uppenberg, K. (2009). Innovation and economic growth. EIB Papers, 14(1), 11-35. 
Uzgören, E. (1999). Bilgi toplumunda uluslararası rekabetedebilirlik avantajının yaratılmasına yönelik stratejik yaklaşım: Devingen yaratıcılık (innovation). Dumlupınar Üniversitesi Sosyal Bilimler Dergisi, 1, 165-176.

Ünsal, E. M. (2016). İktisadi büyüme. Ankara: BB101 Yayınları.

Verspagen, B. (2004). Structural change and technology. A Long View. Revue Economique, Presses de Sciences-Po, 55(6), 1099-1125.

Wong, P. K., Ho, Y. P. ve Autio, E. (2005). Entrepreneurship, innovation and economic growth: Evidence from GEM data. Small Business Economics, 24, 335-350.

www.data.imf.org

Yorulmaz, Ö. (2017). The relationship between socio-economic development, corruption and health indicators: Application of partial least squares structural equation modeling. The Journal of Operations Research, Statistics, Econometrics and Management Information Systems, 5(2), 191-205.

Yülek, M. A. (1997). İçsel büyüme teorileri gelişmekte olan ülkeler kamu politikaları üzerine. Hazine Dergisi, 6, 1-15. 